INTER NATIONAL MONETARY FUND

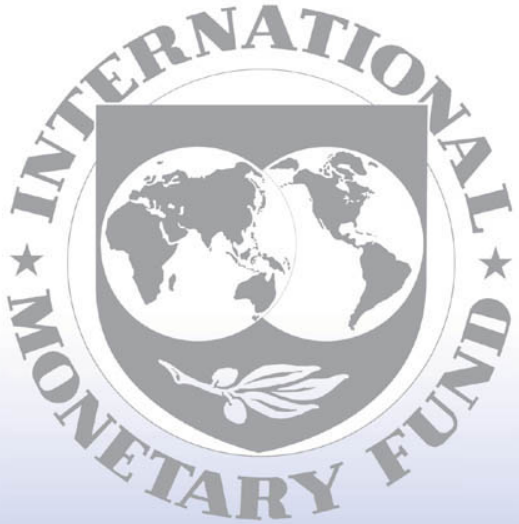

Staff

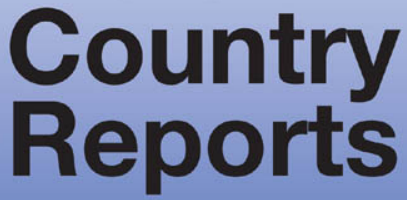




\section{Bangladesh: 2007 Article IV Consultation-Staff Report; Staff Statement; Public Information Notice on the Executive Board Discussion; and Statement by the Executive Director for Bangladesh}

Under Article IV of the IMF's Articles of Agreement, the IMF holds bilateral discussions with members, usually every year. In the context of the 2007 Article IV consultation with Bangladesh, the following documents have been released and are included in this package:

- $\quad$ the staff report for the 2007 Article IV consultation, prepared by a staff team of the IMF, following discussions that ended on April 18, 2007, with the officials of Bangladesh on economic developments and policies. Based on information available at the time of these discussions, the staff report was completed on June 22, 2007. The views expressed in the staff report are those of the staff team and do not necessarily reflect the views of the Executive Board of the IMF;

- $\quad$ a staff statement of June 22, 2007 updating information on recent developments;

- $\quad$ a Public Information Notice (PIN) summarizing the views of the Executive Board as expressed during its June 22, 2007 discussion of the staff report that concluded the Article IV consultation; and

- $\quad$ a statement by the Executive Director for Bangladesh.

The documents listed below have been or will be separately released.

Selected Issues Paper

Statistical Appendix

The policy of publication of staff reports and other documents allows for the deletion of market-sensitive information.

To assist the IMF in evaluating the publication policy, reader comments are invited and may be sent by e-mail to publicationpolicy@imf.org.

Copies of this report are available to the public from

International Monetary Fund $\bullet$ Publication Services

$70019^{\text {th }}$ Street, N.W. • Washington, D.C. 20431

Telephone: (202) 623-7430 • Telefax: (202) 623-7201

E-mail: publications@imf.org • Internet: http://www.imf.org

Price: $\$ 18.00$ a copy

\section{International Monetary Fund Washington, D.C.}


This page intentionally left blank

CInternational Monetary Fund. Not for Redistribution 


\section{INTERNATIONAL MONETARY FUND}

\section{BANGLADESH \\ Staff Report for the 2007 Article IV Consultation}

Prepared by Staff Representatives for the 2007 Consultation with Bangladesh

Approved by Kalpana Kochhar and Anthony Boote

May 31, 2007

Dates: April 3-18, 2007.

Team: Mr. Rumbaugh (head), Ms. Abdelati, Mr. Lueth (all APD), Messrs. Kinoshita (FAD), Alichi (FIN), and Perone (PDR), assisted by the resident representative, Mr. Dunn. Mr. Bannerji (Advisor to Executive Director) participated in the discussions.

Bangladesh government representatives: Chief Advisor Fakhruddin Ahmed, Finance Advisor Mirza Azizul Islam, Finance Secretary Mohammad Tareque, Bangladesh Bank Governor Salehuddin Ahmed, and other senior government officials.

Focus: As part of surveillance under the Article IV consultation, the mission reviewed economic performance over the course of the PRGF arrangement and discussed the transitional government's plans to proceed with a reform agenda.

Previous Board discussion: The fifth PRGF review was completed in October 2006 with back-loaded rephasing, reflecting incomplete progress in the areas of revenue performance and corporatization of the nationalized commercial banks. Directors emphasized the need to mobilize revenue and that no further slippage should be expected for the sixth review. The PRGF Arrangement expires on June 19, 2007 with no possibility for further extension. The previous Article IV consultation was concluded in June 2005.

Exchange system: Managed float; restriction in place on convertibility and transferability of proceeds of current international transactions in nonresident taka accounts.

Statistical issues: Data are adequate for surveillance, but weaknesses remain.

Outreach: The mission made presentations on selected issues to the authorities and met with representatives of donors, NGOs, business, labor, the media, and academics.

Publication: The authorities agreed to the publication of the staff report and selected issues paper. 
Executive Summary $\underline{3}$

I. Political Background and Recent Developments...................................................

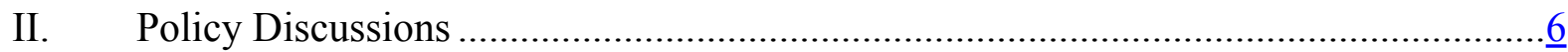

A. Progress Toward Key Objectives of the PRGF-Supported Program .......................... $\underline{6}$

B. Economic Outlook, Development Challenges, and Risks....................................... $\frac{8}{9}$

C. Fiscal Policy and Tax Reform ........................................................................

D. Monetary and Exchange Rate Policies.............................................................

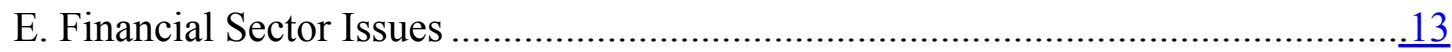

F. SOE, Price, and Governance Reforms...............................................................14

G. Other Issues and Future Fund Engagement ....................................................16

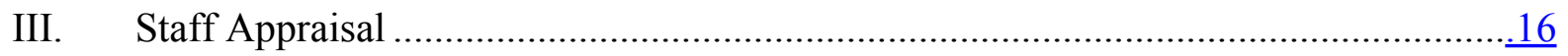

Boxes

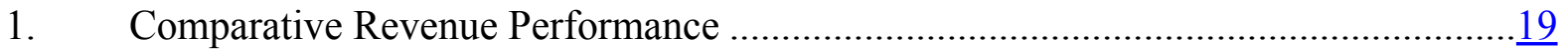

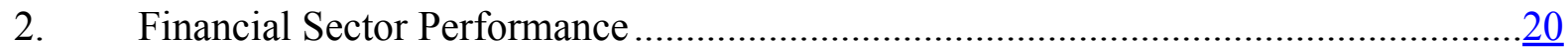

Figures

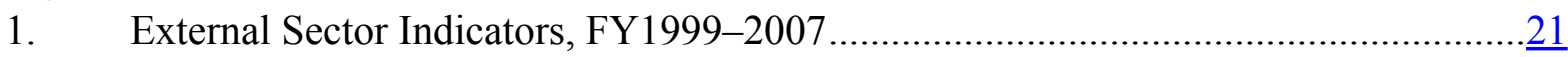

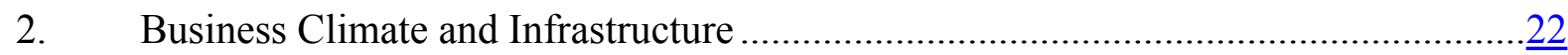

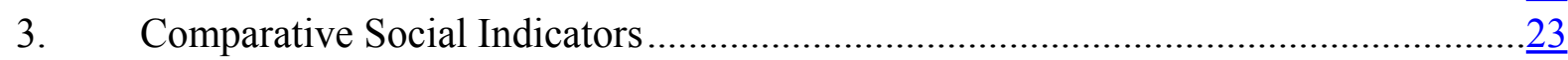

Tables

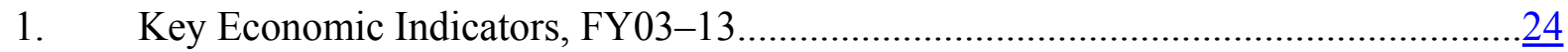

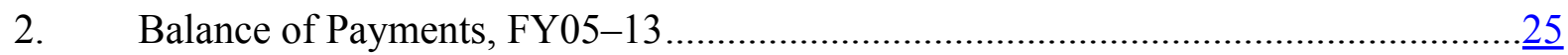

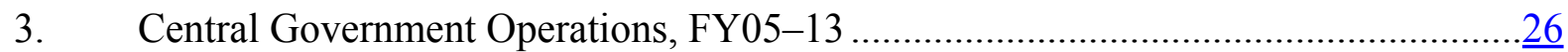

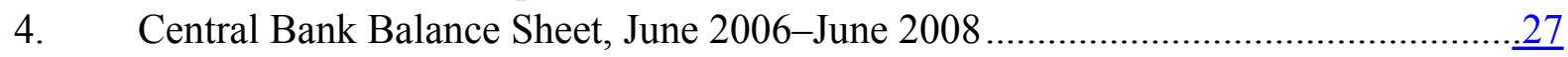

5. Monetary Survey, June 2006-June 2008 ………..............................................

6. Indicative Targets and Quantitative Performance Criteria Under the PRGF

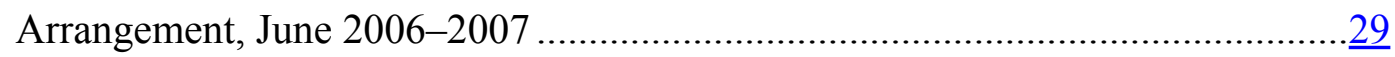

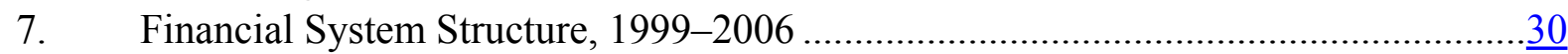

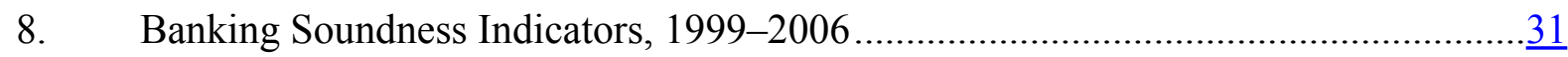

9. Structural Performance Criteria and Benchmarks for the Sixth Review Under

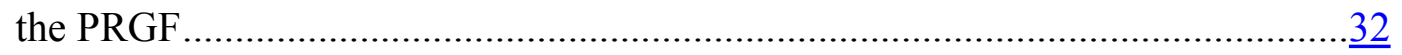

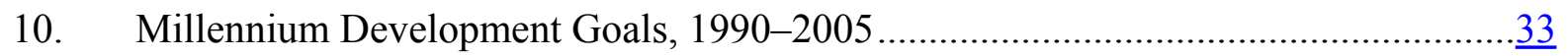




\section{Executive Summary}

\section{Background}

- The growth outlook and external position remain robust, but inflation has picked up. Strong inflows from remittances and exports have contributed to a more comfortable reserve position, but have complicated monetary management.

- Money and credit aggregates expanded at a rapid rate in the first half of the fiscal year and domestic financing of the budget went off track. As a result, several performance criteria were missed. Macroeconomic policies are being brought back in line with program targets, but this process will extend beyond the mid-June expiration date of the PRGF arrangement, precluding completion of the sixth review.

- Most of the macroeconomic objectives of the PRGF program were achieved. A key success is the viability of the external sector, which was transformed following the shift to a flexible exchange rate regime. Although fiscal discipline was maintained, a major disappointment is the failure to significantly raise the low revenue-to-GDP ratio.

- The authorities are targeting a more realistic FY08 budget, with a small increase in revenue supported by specific measures and an increase in development spending consistent with implementation capacity.

- The transitional government has moved forward with a number of previously stalled economic reforms. Recent decisions include significant adjustments in energy prices, corporatization of the nationalized commercial banks, and a range of governance reforms.

\section{Key Policy Issues}

- Staff recommended monetary tightening to curb inflationary pressures. There is also scope for more flexibility in the exchange rate given the improved reserve position.

- Staff argued for fundamental reform of the revenue system to achieve the full benefits of tax administration reform, support further trade reform, and provide resources for the immense development needs.

- Banking risks appear to be manageable, but stricter prudential rules and enforcement are needed to avoid future potential risks particularly in the context of rapid credit growth. Reform of the large insolvent state banks would help improve incentives for greater efficiency of financial intermediation.

- Pricing reform and state-owned enterprise restructuring is still needed. April fuel price increases brought domestic prices more in line with international prices, but further adjustments are needed for fuel, as well as electricity, natural gas, and fertilizer. To increase fiscal transparency, the government plans to assume the nonperforming loans of the petroleum company with the state banks, and this step needs to be supported by measures to avoid future losses. 


\section{Political Background and Recent Developments}

1. Elections that were scheduled for January 2007 did not take place. A few days before the scheduled elections, emergency rule was declared and a transitional government (TG) installed. The Bangladesh Nationalist Party government of Prime Minister Khaleda Zia stepped down on October 28, 2006 and, as required by the constitution, handed over to a caretaker government to prepare for elections within 90 days. However, street protests and blockades escalated as the Grand Alliance, led by Sheik Hasina Wajed of the Awami League, objected to the non-neutrality of the election commission. With Bangladesh facing the almost certain prospect of widespread violence following a one-sided election that the Grand Alliance had decided to boycott, on January 11, 2007, the President stepped down as head of the caretaker government, declared emergency rule, and installed a transitional government.

\section{The TG, which enjoys widespread support for its anti-corruption campaign,} announced that elections would take place before the end of 2008. Led by former Bangladesh Bank (BB) Governor Fakhruddin Ahmed, the TG is moving aggressively to rein in corrupt elements and repair the electoral process to help ensure fair elections. Scores of businessmen and senior officials (including former ministers from both parties) have been arrested and the Anti-Corruption Commission has been empowered to proceed with prosecutions. The Election Commission has been reconstituted and arrangements are in place to create a new voter list and issue voter IDs. The TG has undertaken a number of previously-stalled reforms, motivating the World Bank to proceed with a budget support operation (Development Support Credit IV) that was approved on May 29.

\section{Macroeconomic performance in FY07 has been mixed: growth and external} indicators are sound, but fiscal performance weakened in the first part of the year and inflation has picked up.

- Growth remains strong at a projected $63 / 4$ percent spurred by export demand and rising private domestic investment financed by external current receipts and credit growth. Agriculture rebounded in FY06, but is expected to slow in FY07, while manufacturing and service activity have firmed in the first half of the year. Inflation ( $y / y)$ edged up to over 7 percent by March 2007 reflecting both food and nonfood prices (Table 1).

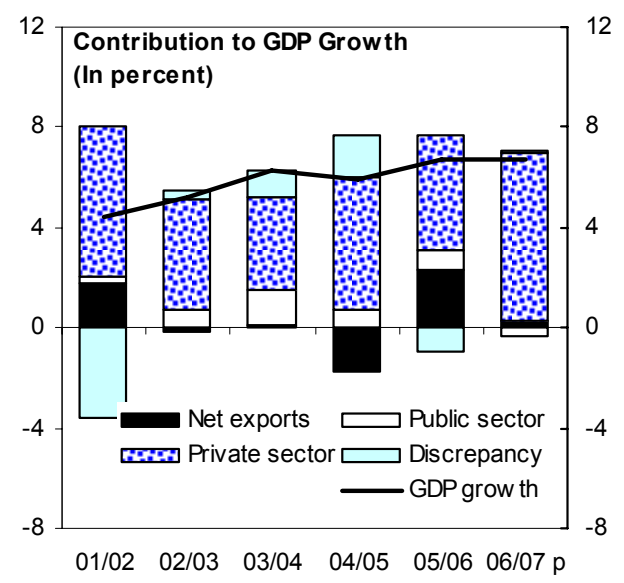


- The exchange rate has been relatively stable, and the reserve buildup continued throughout the political upheaval. Net international reserves at over $\$ 3$ billion have exceeded program targets on the back of continued strong remittances and exports that are growing at annual rates of 25 and 21 percent, respectively (Table 2 ).

- Fiscal performance, however, went off track in the first half of the year. Spending by the outgoing government, coupled with weak revenue collection, pushed domestic financing to well above the end-December PRGF performance criterion. While development spending is being cut back to remain within the budgeted deficit, the annual revenue target is no longer achievable (Table 3).

- Bangladesh Bank did little to further tighten its monetary stance as government credit soared. Broad money growth reached a record high of 22 percent in December and private sector credit grew close to 20 percent. With T-bill rates increasing very gradually (by only $10-22$ basis points since June), BB absorbed a large share of issued government paper and missed its endDecember NDA performance criterion (Tables 4-6). Reflecting better control of government finances since January, end-March NDA had come below the program target, and reserve money declined marginally, but still remains high reflecting the increase in net foreign assets. With ample liquidity, bank lending and deposit interest rates have seen only modest increases (Tables 7-8).

\section{The TG moved swiftly on decisions related to some stalled reforms. It has} approved corporatization of the remaining nationalized commercial banks (NCBs), one of the two PRGF structural performance criteria for March. Three structural benchmarks were met: (i) eliminating overruns in the net open foreign exchange position of the NCBs;

(ii) eliminating the ad hoc treasury system and introducing an auction mechanism with preannounced quantities; and (iii) reviewing and strengthening the existing social safety net programs (to be implemented with the FY08 budget) following a study on ways to mitigate 
the impact of fuel price adjustments on vulnerable groups. However, the structural benchmark related to improving coordination between the large taxpayer units (LTUs), and the remaining structural performance criterion related to assigning unique taxpayer ID numbers to large taxpayers, were not met (Table 9). Nonobservance of several performance criteria and delays in bringing revenue performance in line with program objectives preclude completion of the sixth and final PRGF review before the June 19 expiration of the PRGF arrangement.

5. The pace of reform implementation has also picked up in other areas. In addition to the reforms agreed for the sixth review, the TG approved the sale of the remaining minority shares of Rupali Bank; intervened to manage the failing Oriental Bank that had previously been given effective immunity; adopted pending resolutions on the separation of the judiciary from the executive branch; placed the new container terminal at Chittagong port under private management; raised electricity tariffs by 5 percent in March, and fuel prices by 16-21 percent in April, and established a committee to regularly review and recommend fuel price adjustments. More comprehensive energy sector reforms are being initiated in consultation with the World Bank and the AsDB.

\section{Policy Discussions}

\section{A. Progress Toward Key Objectives of the PRGF-Supported Program}

\section{Most of the PRGF's original macroeconomic objectives have been attained.}

Adoption of a flexible exchange rate regime helped the economy weather the external shocks from the phaseout of MFA quotas and higher oil prices; the overall government deficit remained well below program targets in each year (albeit mainly due to slow project implementation) and domestic financing was contained with the exception of the overrun earlier this year. Moreover, tangible progress was made in bringing several MDG targets within reach, including reductions in the poverty rate, improved access to primary education, gender equality, and reductions in child mortality.

Original Macroeconomic Objectives of the PRGF Program

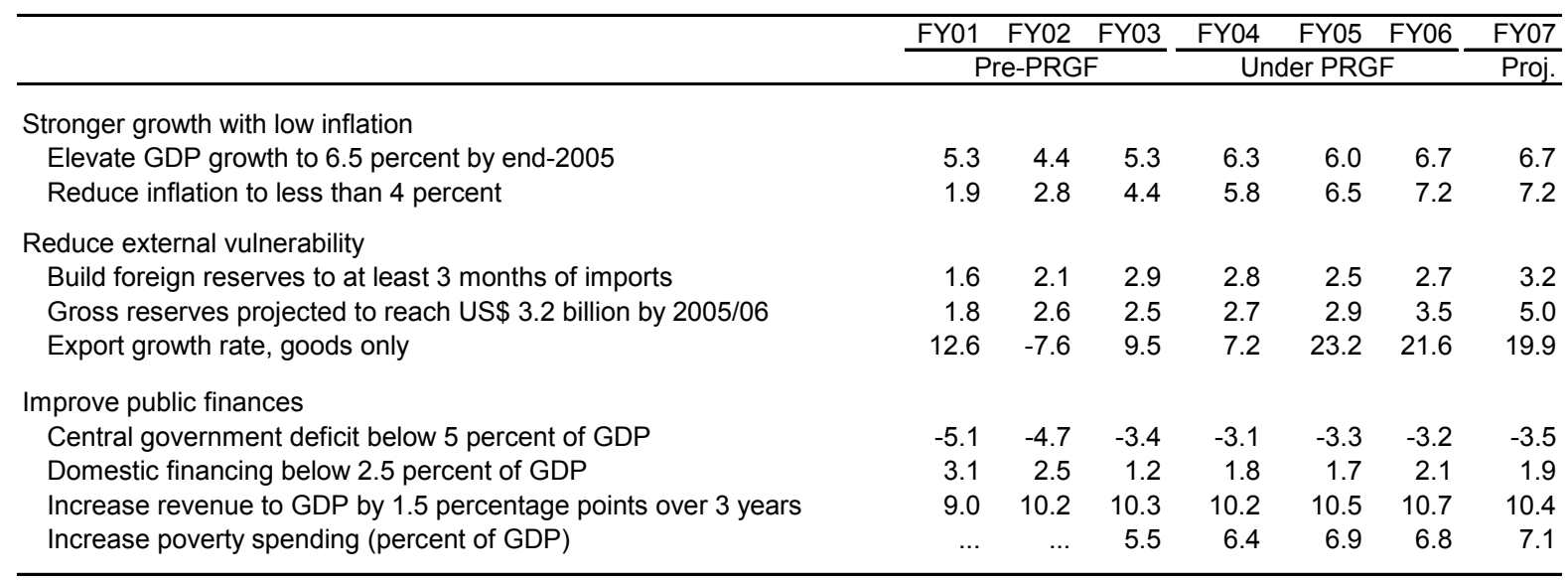

Source: Bangladesh Bank and Fund staff estimates. 
7. However, revenue performance has been a disappointment. The revenue-to-GDP ratio increased by less than $1 / 2$ percent of GDP over four years of the program. Failure to improve revenue mobilization may have resulted from deficiencies in overall tax design, the slower-than-anticipated pace of administrative reforms (due to institutional rigidities), including delays in establishing the LTUs, and lack of improvement in customs administration to limit revenue losses associated with trade liberalization.

8. Structural reforms under the PRGF program generally proceeded at a slow pace with occasional backsliding. The PRGF structural agenda focused mainly on the areas of revenue and NCB reforms, while other critical areas such as governance, state-owned enterprises (SOE) reform, and public finance management were covered by the World Bank, AsDB, and DfID. Although Bangladesh continues to rank low with respect to political stability, regulatory quality, and control of corruption, some progress has been achieved in improving the private sector environment and increasing social spending.

9. Improving the exchange rate system, strengthening central bank operations, and offering for sale one of the smaller NCBs were among the more successful areas of reform. Supported by Fund technical assistance, BB significantly improved the functioning of the foreign exchange market, helping to strengthen confidence in the taka, boost export competitiveness, and safeguard reserves. Similarly, BB improved central bank operations and liquidity management, and its capacity to supervise banks and monitor NCBs' compliance with performance indicators. The latter helped to reduce the share of NCBs in the banking system, limit new lending, and improve operations through new management and agreed performance measures. The privatization of Rupali Bank is an important milestone that would pave the way for divestment of the other three NCBs. With respect to trade liberalization, nominal protection has declined gradually over three years, but the trade regime remains complex and, with nominal protection at 24 percent, further tariff reductions are needed.

\section{Petroleum prices have not kept pace with} international prices leading to a deterioration in SOE finances. An automatic pricing formula for petroleum products was developed in 2003, just

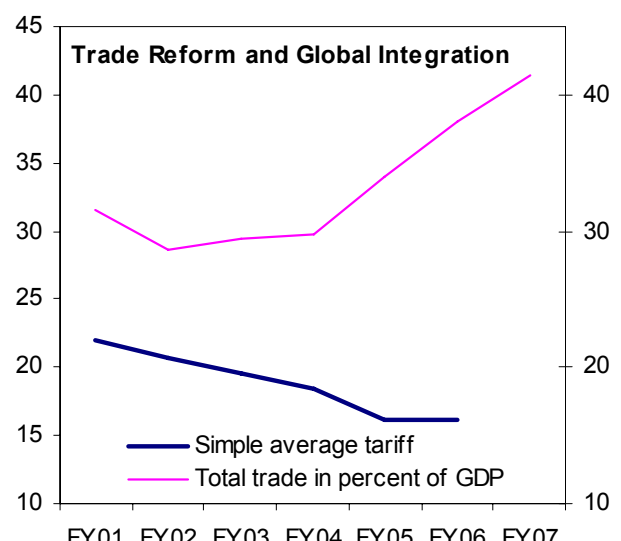

FY01 FY02 FY03 FY04 FY05 FY06 FY07

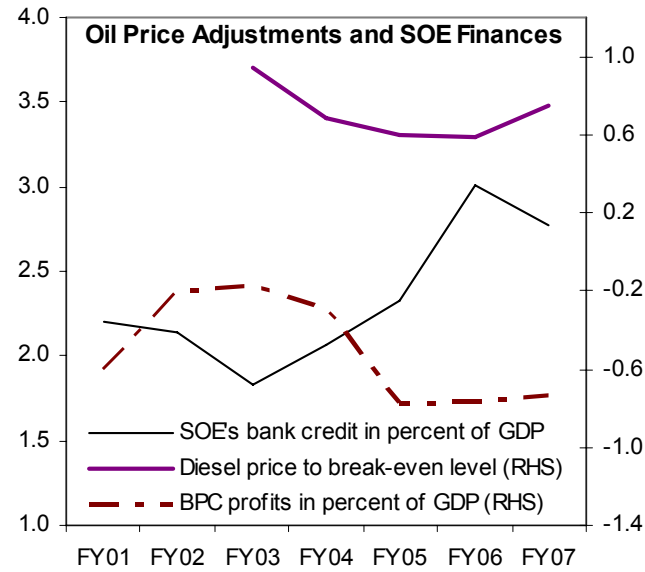
before the surge in oil prices, but never put in practice for fear of widespread popular protest. As a result, and despite several adjustments, diesel prices are still about 20 percent below break-even levels contributing to losses in the state- 
owned petroleum company (BPC), straining the financial performance of NCBs that finance $\mathrm{BPC}$, and complicating monetary management.

\section{The authorities emphasized the improved external position, sustained growth, and poverty reduction as the main achievements under the PRGF-supported}

framework. At the same time, they noted that while there were delays along the way, structural reforms moved forward in all key areas. However, they recognized that revenue collections are still very low compared with other countries and more needed to be done to strengthen both revenue policy and administration.

\section{B. Economic Outlook, Development Challenges, and Risks}

\section{Growth is expected to remain around $6 \frac{1}{2}-7$ percent over the medium term.}

Agriculture is expected to pick up again in FY08 and buoyant garment exports and remittance flows, as well as the possibility of higher aid and private flows, will help sustain investment, including in power infrastructure. Productivity gains are expected to result from infrastructure development and increased emphasis on labor skills training. ${ }^{1}$ Inflation is expected to be contained at around $61 / 2$ percent in FY07, although further pass-through of international oil price increases could temporarily boost prices before inflation begins to decline. The strength of the external sector should sustain double-digit export growth, supported by firming growth prospects in the key European market in FY08. The current account could slip back into a small deficit in FY09 as financing flows and import growth strengthen, but international reserves would increase with higher aid flows and foreign investment.

\section{Providing economic opportunities to the} vast poor population will remain an immense challenge for some time to come. Although strong growth has helped reduce poverty, Bangladesh still lags behind its Asian neighbors in terms of its business climate and on key economic and social

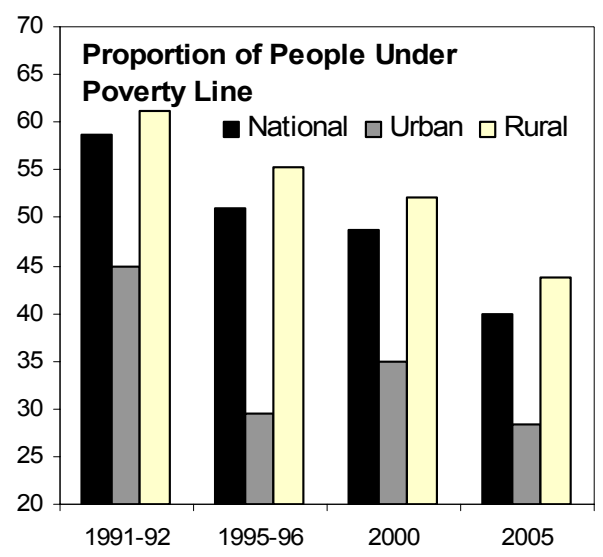
indicators due to deficiencies in social services and infrastructure (Figures 2 and 3). Catching up will entail capitalizing on the regional growth boom to unlock its potential for sustained

\footnotetext{
${ }^{1}$ The sources of growth and future prospects were discussed in a selected issues paper for the 2005 Article IV consultation (IMF Country Report 05/242).
} 
high growth. In addition, improved public finances and better financial intermediation remain key priorities to help provide access to resources and opportunities to the vast poor population. If absorptive capacity were significantly enhanced, increased aid could help remove constraints to allow more progress on poverty alleviation. ${ }^{2}$

\section{A number of risks could lead to slower growth or a weaker external position.}

Although exchange and trade reforms have helped improve resilience to external shocks, the external position is highly dependent on garment exports, which may be vulnerable to intensified competition and shifting sentiments in global markets, although a mild slowdown in major economies would likely have a limited impact on demand for the lower-value-added apparel comprising the bulk of exports. Political stability will be an important factor in sustaining investor confidence; the destructive political rivalry of the last three decades, together with weak accountability and rule of law, has squandered a good portion of available resources. The future outlook will depend to a large extent on the TG's ability to bring about credible elections while maintaining broad public support.

\section{Fiscal Policy and Tax Reform}

\section{Staff commended the authorities' adherence to overall fiscal discipline, but} noted that the quality of fiscal performance continued to be weak. The overall fiscal deficit and domestic financing have been contained to below 4 percent and 2 percent of GDP respectively, but as noted above, revenue shortfalls persisted. In addition, a deterioration of SOE finances and mounting arrears between state entities have undermined the public sector's financial position, and structural rigidities have persistently hampered implementation of the development budget.

\section{Recognition of these weaknesses was largely} shared by the authorities. They explained that raising revenue has been particularly challenging in the context of trade reform, but concurred with the need to broaden the tax base and continue to shift away from trade taxes. The staff welcomed the current government's intention to consider revenue reforms, strengthen public financial management, restructure SOEs, and improve fiscal transparency.

17. The staff strongly encouraged the authorities to initiate fundamental reform of the

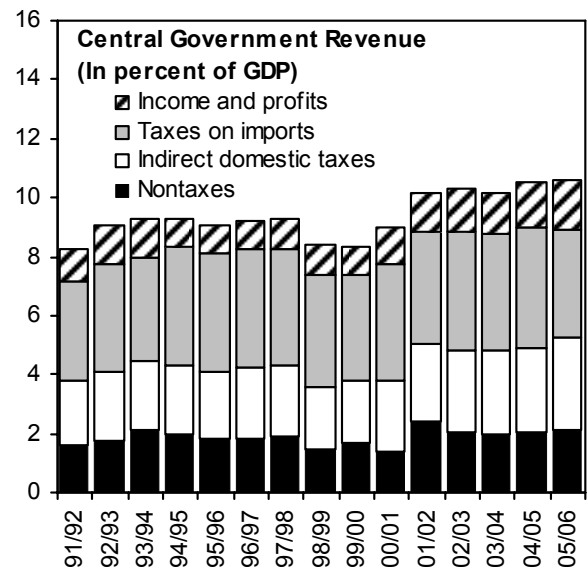
revenue system. A recent FAD tax policy mission saw little scope for improving tax revenue

\footnotetext{
${ }^{2}$ Accompanying selected issues papers explore aid flows and utilization, and the important role played by remittances.
} 
collection from administration reforms alone and recommended a complete overhaul of tax legislation (Box 1). Staff suggested that the next steps to initiate such reform would entail: (i) clearly separating tax policy from administration; (ii) forming a tax reform commission that would oversee the process; and (iii) confirming that no further tax holidays will be granted after their planned expiration at end-June 2008. The authorities accepted that addressing the persistent revenue shortfalls in a sustainable way is the key fiscal challenge and they are considering action in all of these areas. FAD has expressed willingness to provide follow-up assistance when the authorities confirm their readiness to move forward with key reforms.

\section{Further efforts are needed to augment ongoing revenue administration reform.} Staff observed that establishment of the LTUs has been an important step, and the pickup in revenue collected by the income tax LTU is an important sign of the potential collection gains. To reinforce these efforts, staff recommended consolidation of the income tax and VAT units into a single LTU as operations would benefit considerably from better cooperation, information sharing, and joint audits of taxpayers. The government is considering possible ways to implement this recommendation within existing civil service and institutional constraints. The authorities were also urged to complete the introduction of single large taxpayer ID numbers and to strengthen the operations of the Central Intelligence Cell.

\section{In the FY08 budget, the authorities intend to aim at a modest increase in} revenue. The authorities are planning for an increase in revenue to 10.7 percent of GDP based on adjustment of land values used in assessing property transfer fees, increases in vehicle registration fees, and possibly eliminating tariff exemptions and moving some zero-rated items to a higher duty rate. The staff also saw merit in considering measures such as increases in nonfuel excises; an adjustment in prices of domestically produced natural gas, which is substantially below opportunity cost; and adjusting the top marginal personal income tax rate from 25 percent to 30 percent to align it more closely with the

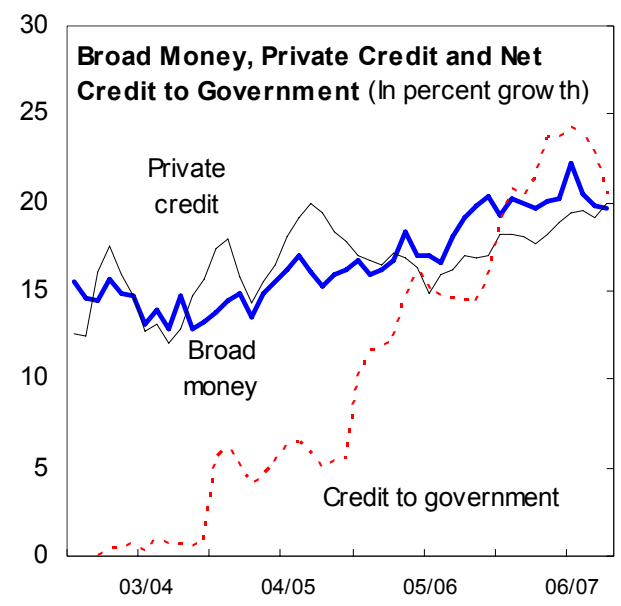
corporate tax rate. Further reducing exemptions and better revenue administration would help supplement revenue performance while a more fundamental reform of the revenue system is initiated.

\section{Expenditure priorities in FY08 will focus on higher social safety net spending} and a 0.6 percent of GDP increase in the annual development program. The overall budget deficit is targeted to increase to 5.2 percent of GDP after assuming the stock of nonperforming loans of the BPC with domestic banks amounting to 1.6 percent of GDP. These nonperforming loans represent two-thirds of the total stock of BPC's bank borrowing to finance its losses over the years. The underlying deficit (i.e., the overall deficit excluding 
the impact of assuming SOE debt) would remain around 31/2 percent of GDP. With respect to public financial management, the planned expansion of the medium-term budget framework (MTBF) to four additional ministries (for a total of 14) during FY08 paves the way for a more consolidated MTBF. Moreover, adoption of a regulatory framework to implement the Public Procurement Act of June 2006 will help improve the efficiency of expenditure and project implementation.

\section{The authorities have requested technical assistance (TA) to further improve} their debt management capacity. MCM is considering how best to address this request. The analysis and conclusions of the most recent debt sustainability analysis (DSA)(IMF Country Report No. 06/406, November 2006), showing low risk of external debt distress and moderate risk of public debt distress, remain fundamentally valid. Bank and Fund staff intend to initiate the next update of the DSA in early 2008 in line with the expected timing of the 2008 Article IV consultation, and to involve the authorities in its preparation. Improving debt management and enhancing absorptive capacity would be especially important if additional aid flows materialize.

\section{Monetary and Exchange Rate Policies}

\section{Staff saw a need for further monetary tightening in the face of strong inflows} and rising inflation. In recent months, ample liquidity (arising from strong exports and remittances) has emerged as the main challenge for monetary policy. In the face of rapid credit expansion, money market rates have remained unchanged since mid-2006, and banks' excess reserves have risen above levels envisaged in the program. Although currency growth has declined in the last three months, monetary aggregates continue to exceed program targets.

\section{In its January policy statement, BB stated its intention to keep unchanged its} policy of "cautious restraint" with a view to support real GDP growth of 7 percent so long as inflation remains below 7 percent, but called for greater restraint in bank borrowing by the public sector. The staff noted that the recent jump in inflation above 7 percent, coupled with the expected impact of the April hike in fuel prices, reinforced the need for some monetary tightening to firmly anchor inflationary expectations. The authorities were more optimistic than staff that overall inflation would come back below 7 percent by the end of the fiscal year as supply

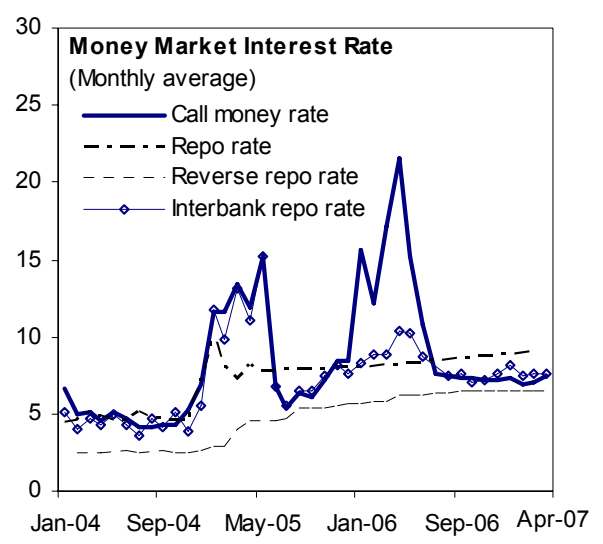
constraints eased, and that an early tightening of policy might dampen growth momentum. They have taken some administrative measures to control commodity prices (see 936 ) and pledged to monitor the situation closely in the coming months. The next monetary policy statement is expected to be released in July. 
24. Following on the advice of MCM TA, progress has been made in moving more toward the market-based conduct of monetary policy. The government's borrowing requirement has become more predictable with broad adherence to the auction calendar for government securities announced in September 2006. The Ministry of Finance is preparing the grounds for secondary market and yield curve development and has issued a large share of long-term securities this fiscal year. Recent steps taken to encourage activity of primary dealers will reduce the need for BB to absorb primary issues of government securities. Over time, this should facilitate increased reliance on transactions in government securities in the secondary market as the main instrument of monetary policy, supported by repos/reverse repos and sales of BB securities as needed. As a next step, the authorities agreed to consider staff's recommendation of eliminating the up-front tax on government securities, which distorts security pricing and may undermine the development of a secondary market.

\section{The staff supports the continued adherence to the flexible exchange rate regime,}

with interventions confined to countering disorderly conditions and building reserves to targeted levels. In recent years, the exchange rate has depreciated in real effective terms in response to the phaseout of MFA quotas and increases in international oil prices. This adjustment has maintained competitiveness - as reflected in sustained growth in exports and remittances — and allowed the authorities to increase international reserves in line with (and recently beyond) program targets. ${ }^{3}$

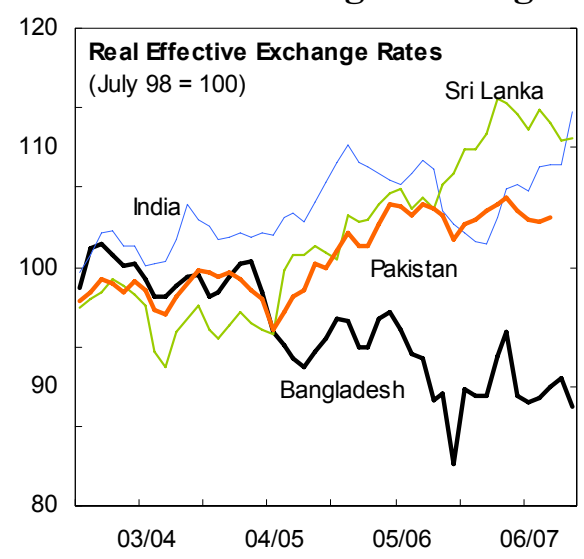

26. The staff saw scope for more exchange rate flexibility to support the objectives of monetary policy. The central bank's purchase of over $\$ 400$ million from the market since January has restrained taka appreciation in the face of strong inflows. Along with monetary tightening, staff also advised there was scope to moderate the pace of reserve accumulation and allow for greater flexibility in the exchange rate. Given the more comfortable reserve position, staff also urged removal of the restriction on the transferability of proceeds from nonresident taka accounts (Annex I). The authorities emphasized that their intervention policy is geared toward stabilizing market conditions and taking advantage of opportunities to increase their international reserve position, in line with the commitments they have made in their Memorandum of Economic and Financial Policies. In principle, they were willing to accept more movement in the exchange rate going forward in line with market conditions. With respect to the exchange restriction, they still saw a small risk that removing it could precipitate capital outflows and were not willing to commit to a specific timetable for its removal.

\footnotetext{
${ }^{3}$ A selected issues paper explores the competitiveness of the garment sector.
} 


\section{E. Financial Sector Issues}

\section{Bangladesh Bank (BB) has advanced reforms aimed at deepening financial}

markets. The regulatory framework has been strengthened, off-site and on-site supervision has been enhanced and steps taken to restructure, corporatize, and privatize the large nationalized comercial banks (NCBs). However, the observed improvements in published aggregate indicators of bank soundness conceal wide divergences in individual banks' performance and mask underlying weaknesses in the banking system due to underestimation of the capital shortfall.

\section{Financial sector risks appear to be manageable, but further efforts are needed to} strengthen the monitoring framework. The authorities noted that many recommendations from the 2002 Financial Sector Assessment Program (FSAP) have been implemented, but agreed with the staff that much more remains to be done to bring regulatory standards in line with international norms. For example, while capital standards and risk weights are broadly consistent with the Basel framework, lenient classification rules and noncompliance means that some banks are underprovisioned and undercapitalized (Box 2). After Rupali's divestment, the capital shortfall of the three remaining NCBs will be around 2 percent of GDP when adjusting for required provisioning shortfalls (doubling to 4 percent of

\begin{tabular}{|c|c|c|c|c|c|}
\hline \multicolumn{6}{|c|}{$\begin{array}{l}\text { Bangladesh: Banking Indicators, 2001-06 } \\
\text { (in percent) }\end{array}$} \\
\hline & Dec 02 & Dec 03 & Dec 04 & Dec 05 & Dec 06 \\
\hline \multicolumn{6}{|l|}{ Share of banking system assets } \\
\hline Nationalized commercial banks & 47 & 44 & 42 & 39 & 35 \\
\hline Specialized development banks & 9 & 8 & 8 & 7 & 6 \\
\hline Private commercial banks & 35 & 39 & 42 & 44 & 48 \\
\hline Foreign commercial banks & 9 & 10 & 8 & 10 & 10 \\
\hline Adjusted capital to risk-weighted assets $1 /$ & -0.6 & 1.1 & 0.1 & 1.8 & 2.3 \\
\hline Nationalized commercial banks & -7.5 & -14.9 & -13.7 & -10.4 & -9.6 \\
\hline Specialized development banks & -6.8 & -6.0 & -6.9 & -10.0 & -10.9 \\
\hline Private commercial banks & 7.3 & 13.1 & 9.4 & 8.7 & 8.1 \\
\hline Foreign commercial banks & 22.2 & 40.2 & 24.7 & 26.1 & 22.7 \\
\hline Net asset growth & 6.5 & 6.4 & 17.0 & 17.8 & 14.9 \\
\hline Nationalized commercial banks & 12.7 & -2.0 & 10.0 & 10.1 & 3.1 \\
\hline Specialized development banks & -19.1 & -12.7 & 27.5 & 10.8 & 10.9 \\
\hline Private commercial banks & 12.5 & 18.2 & 28.2 & 22.5 & 24.5 \\
\hline Foreign commercial banks & -12.5 & 16.7 & -3.1 & 34.6 & 17.9 \\
\hline Capital shortfall in percent of GDP 1/ & 1.83 & 2.50 & 2.86 & 2.44 & 2.35 \\
\hline Nationalized commercial banks & 1.89 & 2.75 & 2.43 & 2.00 & 1.81 \\
\hline Specialized development banks & 0.07 & 0.56 & 0.60 & 0.66 & 0.70 \\
\hline Private commercial banks & -0.01 & -0.38 & 0.00 & 0.08 & 0.16 \\
\hline Foreign commercial banks & -0.12 & -0.44 & -0.17 & -0.30 & -0.32 \\
\hline
\end{tabular}
GDP if international loan classification and provisioning rules were applied). In addition, there is an estimated capital shortfall of 2-3 percent of GDP in the four development banks, mainly due to the government's repeated loan forgiveness to clients without compensating the banks. Three out of 40 private banks do not meet the required 9 percent capital adequacy ratio and are on BB's closely-watched list.

\section{The staff called for more vigilance in implementing the NCB restructuring and} divestment program to help promote banking sector soundness. Privatization of Rupali and corporatization of the three remaining NCBs will bring them more directly under BB's supervision. The staff agreed with the authorities that to be effective, corporatization will need to be accompanied by appointment of qualified directors who can guide and implement the restructuring programs at these banks. The government should also review the role of the development banks in achieving its policy objectives and ways to improve their performance. 
30. Improving NCB performance would also help enhance financial intermediation.

Although the share of state banks' assets has significantly declined, the continued dominance of these banks diminishes incentives to improve the overall performance of the sector by providing scope for the existence of some weak private commercial banks while the more efficient ones can collect high rents. Interest rate spreads are high by comparative standards and inefficiencies of the domestic banking system are allowing foreign banks to reap large profits.

\section{Bangladesh Bank officials concurred with the need to further strengthen banking} regulations and more closely monitor rapid credit growth for potential future risks. Assets of private domestic banks have been growing at 22-28 percent annually for the past three years, and lending by some smaller banks has grown by an average of 30-40 percent. Recently introduced provisions will facilitate bank mergers and help achieve some consolidation for the smaller weaker banks. The staff welcomed the proposed amendments to the Banking Companies Act that will enable BB to strengthen loan classification standards and to gradually raise banks' minimum capital requirements. Bangladesh Bank has been conducting a self-assessment

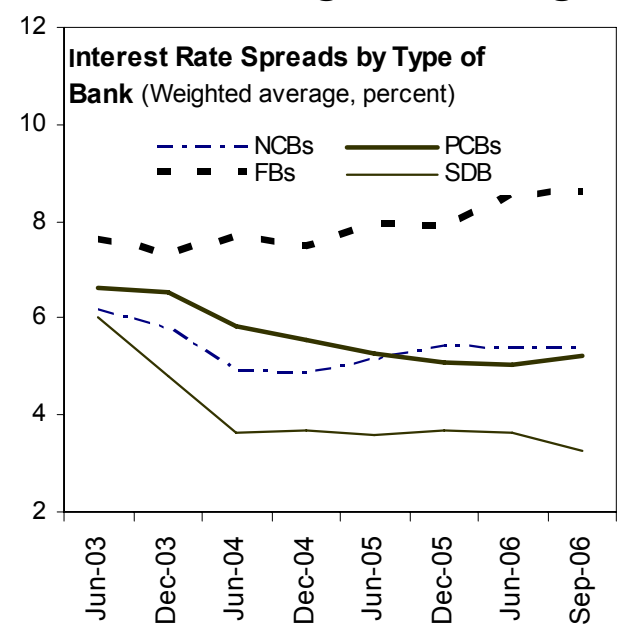
of its implementation of the recommendations of the 2002 FSAP and has requested an IMF/WB mission to review their findings and conduct an FSAP update.

\section{F. SOE, Price, and Governance Reforms}

\section{The staff saw an urgent need to address} accumulating quasi-fiscal losses of SOEs. April fuel price adjustments of 21 percent for petrol, and 16 percent for diesel and kerosene, will bring annual losses down from around $3 / 4$ percent of GDP in FY06 and FY07 to about $1 / 2$ percent of GDP in FY08 in the absence of further changes in domestic or international prices. At current levels, domestic prices are at 88 percent of break-even levels on average, with diesel prices exhibiting the widest gap at 80 percent of the break-even level and considerably below prices in bordering India.

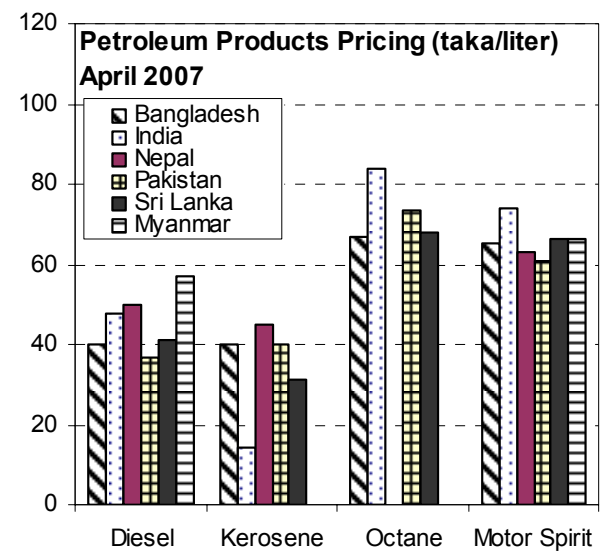

\section{The staff welcomed the authorities' intention to resolve BPC's losses in a}

transparent manner. The BPC's losses accumulated in the past and its associated overdue loans from NCBs, amount to 1.6 percent of GDP. The mission supported the authorities' intention to issue government securities to assume the overdue loans and to make necessary provisions in the budget. However, to avoid the re-accumulation of losses in BPC, it would be important to: (i) introduce an automatic mechanism of price adjustment; (ii) improve the 
operational efficiency of BPC; and (iii) ensure that BPC increasingly seeks trade financing on commercial terms without a government guarantee.

\section{Price adjustments and financial restructuring of other loss-making SOEs are}

also needed. BPC alone accounts for about two-thirds of accumulated SOE losses, with the state airline, fertilizer, and power companies accounting for the remainder. ${ }^{4}$ Further adjustments in electricity tariffs and fertilizer prices, and financial restructuring of the stateowned electricity companies, will be needed. Besides pricing reform and financial restructuring, there is scope for further divestment from among the remaining $47 \mathrm{SOEs}$, and the World Bank and AsDB are working with the authorities on regulatory reform to promote investment in expanding power generation.

35. Staff reiterated the merits of adjusting natural gas prices. The pricing of natural gas is considerably below international levels, resulting in the forfeiture of a significant source of government revenue and creating substantial market distortions by encouraging conversion to $\mathrm{CNG}$ as a source of fuel. Higher gas prices will imply a need for further adjustment in electricity and fertilizer prices, but reform of energy sector policy will be incomplete and distortionary unless adjustment of gas prices is included. The authorities indicated their intention to continue with adjustment of administrated prices to put SOE finances on a sound basis, but were reluctant to consider adjustment of natural gas until petroleum, electricity, and fertilizer price adjustments are completed.

36. Staff warned that recent administrative measures to control commodity prices may be counterproductive. The authorities are understandably concerned by increases in the prices of some basic food commodities. Staff, however, advised that some of the government's ongoing and proposed administrative measures that seek to regulate stock levels and pricing policies of private traders could have created market distortions and uncertainty in the business environment, thereby contributing to shortages and additional price pressures. Staff encouraged the authorities to contain emerging inflationary pressures through appropriate monetary and exchange rate policies. In conjunction with macroeconomic policies, staff strongly supported the authorities' efforts to enhance targeted social safety net programs to provide assistance to the poor and protect their consumption possibilities.

37. Tackling governance problems is crucial for improving the investment climate. Donors have welcomed the government's recent emphasis on governance reforms and are providing capacity-building support. The capacity of the Ministry of Finance to oversee public expenditure and the Comptroller and Auditor-General's office to carry out independent audits are being strengthened. Following reconstitution of the Anti-Corruption Commission, filing of dozens of corruption charges and launching an investigation period,

\footnotetext{
${ }^{4}$ A selected issues paper takes stock of SOE finances and their contribution to public sector performance.
} 
the first three cases of corruption charges of former senior government officials were initiated by the special courts. The anti-money laundering and combating the financing of terrorism (AML/CFT) framework is also being strengthened, most recently with the initiation of a Financial Intelligence Unit in May 2007. To improve fiscal transparency, the government now includes a list of government guarantees in the budget document and is taking steps to reflect SOE losses directly in the budget.

\section{G. Other Issues and Future Fund Engagement}

38. Economic data are adequate for surveillance, but significant weaknesses remain. Planned Fund TA will support the authorities' efforts to address deficiencies identified in the 2005 ROSC in the areas of national accounts, balance of payments, debt monitoring, and government finance statistics.

39. A full PRSP was completed in November 2005. Work has been initiated on a PRSP implementation report that is expected to be completed by end-2007.

40. The authorities are keen to advance the reform agenda under their tenure. The Chief Advisor and Finance Advisor confirmed their preparedness to move on the critical areas of comprehensive overhaul of the revenue system, improvements in fiscal transparency, administrative reforms of NBR, and further financial sector reforms, and have expressed interest in a new PRGF arrangement. The staff considers that an arrangement would support further structural reforms and continued macroeconomic stabilization. In addition to the recently approved Development Support Credit (DSC-IV) of \$200 million, the World Bank has scheduled a Board discussion for an education sector policy loan ( $\$ 100$ million) in June 2007, and is planning a possible follow-up budget support operation in 2008.

\section{STAFF APPRAISAL}

\section{Most of the PRGF's macroeconomic objectives were achieved in the last four} years. Growth has averaged 6.4 percent, inflation was largely contained, international reserves increased to around three months of import coverage, and the fiscal deficit and public debt were contained despite revenue shortfalls. Moreover, the poverty headcount declined by 2 percentage points annually and several MDG targets are within reach. However, revenue targets under the program were consistently missed and progress in some key areas of structural reform was less than envisaged.

\section{With sustained reform efforts, growth is expected to remain around}

6 $1 / 2-7$ percent. Broad-based growth with low inflation, and revenue enhancement to finance social programs, are both crucial for further reducing poverty. In addition to reliance on buoyant export and remittance flows, and possibly higher foreign investment and aid flows, investment impediments - infrastructure and skill deficiencies, power shortages, and perceptions of corruption — need to be addressed. 
43. Exchange rate reform was among the principal successes under the PRGFsupported program, facilitating double digit export growth in the post MFA era and attainment of a more comfortable reserve position. Other areas of progress include lessening dependence on central bank financing, strengthening central bank operations and its monitoring of the financial sector, and corporatization of the large insolvent nationalized banks to facilitate their restructuring and eventual sale.

44. However, revenue performance was a disappointment. At around $10 \frac{1}{2}$ percent of GDP, revenue collection is among the lowest in the world, inadequate to meet the pressing social spending needs, and virtually unchanged over the last four years compared to a programmed annual increase of $1 / 2$ percent of GDP — pointing to inadequate efforts to date.

45. Fundamental reform of the tax system should be a central component of fiscal policy going forward. Responsibility for tax policy and collection should be separated while VAT and income tax legislation should be redrafted to reduce exemptions and make the laws easier to administer. In the meantime, stronger efforts should be made to cut back on exemptions and broaden the tax base to supplement revenue performance.

46. Ongoing tax administration measures also need to be more effectively executed. Merging the LTUs would improve their effectiveness by pooling information and resources.

47. Revenue reforms would also allow for further reduction in tariffs and supplementary duties. Although there has been a welcome shift away from reliance on trade taxes, it has been constrained by insufficient efforts to mobilize alternative revenue sources, and nominal protection remains among the highest in the region.

48. Public financial management reforms would help improve the efficiency of expenditure and project implementation and could help to attract more donor resources. Following the adoption of MTBF in 14 ministries, the overall budget should be prepared within a medium-term framework. Impediments to implementation of the annual development program will need to be addressed to improve budget execution.

49. SOE reforms are needed to curb fiscal costs and ease infrastructure bottlenecks. To stem future accumulation of losses, the government should combine plans to assume the nonperforming loans of the petroleum company with operational restructuring measures and an automatic price adjustment mechanism, and initiate price and governance reforms in the other major public enterprises.

50. Bangladesh Bank should build on recent financial sector reforms. Monitoring should be strengthened in the context of rapid credit growth by some banks, and regulations need to be brought more in line with international standards - and be more strictly enforced - so that bank soundness can be more accurately assessed. Staff welcomes the authorities' initiation of a self-assessment of the FSAP recommendations, and their preparedness for an FSAP update. 
51. Further monetary tightening would help curb inflationary expectations. Recent hikes in food and fuel prices are expected to drive up inflation temporarily and could, in the absence of corrective policies, propel inflation into FY08. Developing a secondary market for securities would contribute to enhancing monetary policy and support financial sector development.

\section{Improvements in the external position should provide scope for further} development of the foreign exchange market. The flexible exchange rate regime has helped maintain competitiveness in the face of external shocks and the factious domestic political climate, and remains appropriate. There is no evidence of a significant misalignment in the rate given recent performance of exports and remittances. Now that international reserves are at more comfortable levels, confining intervention to stabilizing disorderly market conditions will allow for more flexibility in the nominal rate and support stabilization objectives. The remaining exchange restriction on the transferability of funds in nonresident taka accounts should be removed and, given the lack of a specific timetable for its removal, staff does not recommend approval of the restriction.

53. Staff welcomes the recent emphasis on governance reforms. Ongoing reforms that aim to ensure more transparency and good governance in public administration, operation of public service facilities, the election process, the prevention of money laundering and terrorism financing, and in the judiciary will, if sustained, upgrade Bangladesh's relatively low ratings thereby giving a boost to the investment climate.

\section{Continued efforts to address deficiencies in economic statistics will also be}

needed. The authorities are encouraged to give more priority to upgrading statistics and to make good use of forthcoming technical assistance.

55. It is recommended that the next consultation with Bangladesh take place within the standard 12-month cycle. 


\section{Box 1. Bangladesh: Comparative Revenue Performance}

Revenue performance improved slightly during the PRGF-supported program, but fell short of program objectives and remains one of the lowest for PRGF-eligible countries. At $81 / 2$ percent of GDP, tax revenue compares unfavorably with an average of 13 percent in other Asian countries and 15 percent of GDP in subSaharan African countries.

Tax rates are not low, but rather the tax system is inefficient. The statutory nominal tax rates for VAT and corporate income tax are comparable to or higher than in other countries. However, revenue yields are low; Bangladesh's revenue productivity (the tax-to-GDP ratio divided by the applicable nominal tax rate) is lower than for other Asian countries. ${ }^{1}$

There are multiple reasons for the weak

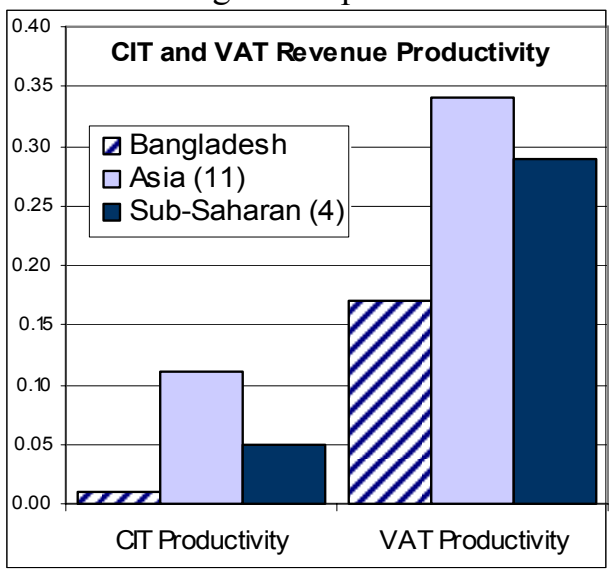
performance. A recent FAD TA tax policy mission identified several reasons for low efficiency in revenue collection: (i) excessive use of tax holidays; (ii) basic design flaws of key tax laws; and (iii) poor compliance. The mission determined that prospects for securing a significantly higher tax-to-GDP ratio would not be good without fundamental reform of the tax system involving among other things redrafting of key legislation.

The objective of fundamental tax reform is a simplified tax system, with reduced exemptions, less discretion, and improved compliance.

- The authorities estimated revenue foregone from tax expenditures at $2 \frac{1}{2}$ percent of GDP, of which almost 90 percent was from indirect taxes. The staff considers the potential revenue gain could be larger in the case of direct taxes due to pervasive income tax incentives, and much smaller

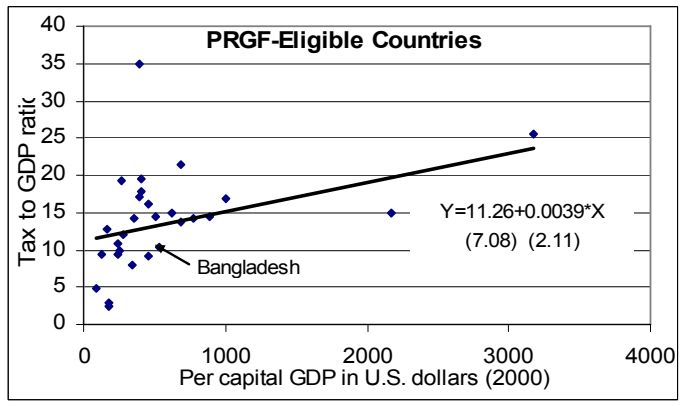
for indirect taxes since the estimate includes VAT exemptions on bank interest (not normally subject to VAT) and on intermediate inputs (that are creditable at a later stage).

- Estimates based on cross-country regressions on tax-to-GDP ratios and revenue productivity for selected countries suggest that there is scope to raise the tax-to-GDP ratio by 2-4 percent of GDP over the medium term from a combination of tax system and administrative reforms (including the eventual merger of the LTUs) for a country at Bangladesh's income level.

\footnotetext{
${ }^{1}$ These issues are covered in more detail in a selected issues paper.
} 


\section{Box 2. Bangladesh: Financial Sector Performance ${ }^{1}$}

The financial sector is dominated by commercial banks, which account for 90 percent of financial system assets. With broad money and total credit at 40 and 30 percent of GDP, respectively, financial deepening lags behind most Asian countries.

Banking system performance has improved overall with increased competition and strengthened regulation and supervision. Entry of new banks following financial liberalization helped stimulate financial intermediation, reducing the share of the four nationalized banks (NCBs) and five specialized development banks (SDBs) from 68 percent in 1997 to 41 percent of banking assets in 2006 .

- Asset quality indicators have improved, but provisioning remains low. The last FSAP found that in 2002, 35 percent of NCBs' and 56 percent of SDBs' loans were nonperforming and these have declined to 23 and 34 percent, respectively. Only 4 out of 30 private banks have NPL ratios in excess of 10 percent compared to 11 banks in 2002. However, rapid credit growth may be masking NPL ratios and provisioning remains low except in the foreign banks.

- High interest rate spreads point to widespread inefficiencies. Operational inefficiencies of NCBs have allowed foreign banks to benefit from high spreads and reap a return of 4 percent on assets.

\section{Recent deposit and credit growth is a} welcome sign of financial deepening, but need to be monitored for potential risk factors.

\begin{tabular}{|lrrr|}
\hline \multicolumn{4}{|c|}{$\begin{array}{c}\text { Bank Performance Indicators } \\
\text { (in percent) }\end{array}$} \\
& & & \\
Dec 02 & Dec 05 & Dec 06 \\
\cline { 2 - 4 } NPLs to gross loans & 28 & 14 & 13 \\
Nationalized commercial banks & 34 & 21 & 23 \\
Specialized development banks & 56 & 35 & 34 \\
Private commercial banks & 17 & 6 & 5 \\
Foreign commercial banks & 3 & 1 & 1 \\
Provisioning ratio & 25 & 24 & 26 \\
Nationalized commercial banks & 16 & 13 & 16 \\
Specialized development banks & 28 & 24 & 22 \\
Private commercial banks & 42 & 50 & 52 \\
Foreign commercial banks & 115 & 215 & 363 \\
Interest margin to average assets & 1.4 & 2.3 & 2.0 \\
Nationalized commercial banks & 0.7 & 1.5 & 1.1 \\
Specialized development banks & 1.9 & 1.3 & 1.2 \\
Private commercial banks & 1.9 & 2.9 & 2.4 \\
Foreign commercial banks & 1.9 & 4.1 & 3.6 \\
Return on assets & -0.2 & 2.2 & 1.3 \\
Nationalized commercial banks & -0.2 & 2.1 & 0.5 \\
Specialized development banks & 0.5 & -3.4 & -3.3 \\
Private commercial banks & 1.7 & 2.5 & 1.8 \\
Foreign commercial banks & 3.3 & 3.9 & 4.1 \\
\hline Source: Bangladesh Bank and Fund staff estimates. \\
\hline
\end{tabular}

Private bank lending has increased by an average of 35 percent annually over the last three years, and high loan-to-deposit ratios of some banks suggest rising liquidity constraints. Available data do not point to risks from sectoral loan concentration: short-term trade finance and working capital together account for 50 percent of total loans outstanding (and two-thirds of all loans are of less than one year maturity). Housing credit is estimated at less than 5 percent of total lending in 2005. Lending in foreign currency is mainly confined to trade-related credits, and most banks are within BB's limits of net open positions, thereby limiting vulnerability to foreign exchange risk.

\footnotetext{
${ }^{1}$ These issues are covered in more detail in a selected issues paper.
} 
Figure 1. Bangladesh: External Sector Indicators, FY1999-2007
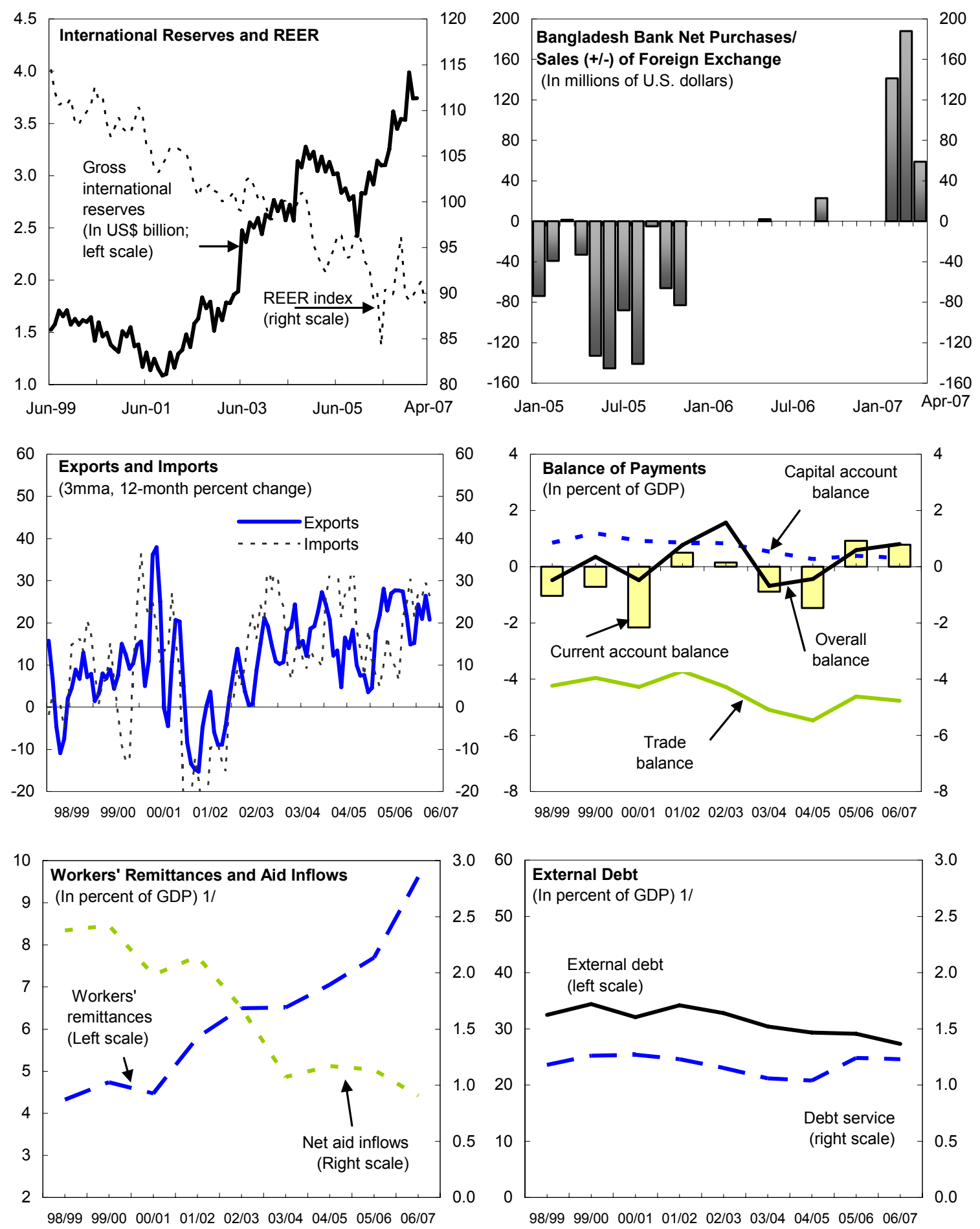

Sources: Data provided by the Bangladesh authorities; IMF, Information Notice System, International Financial Statistics; and Fund staff estimates and projections.

1/ Proiection for 06/07. 
Figure 2. Bangladesh: Business Climate and Infrastructure
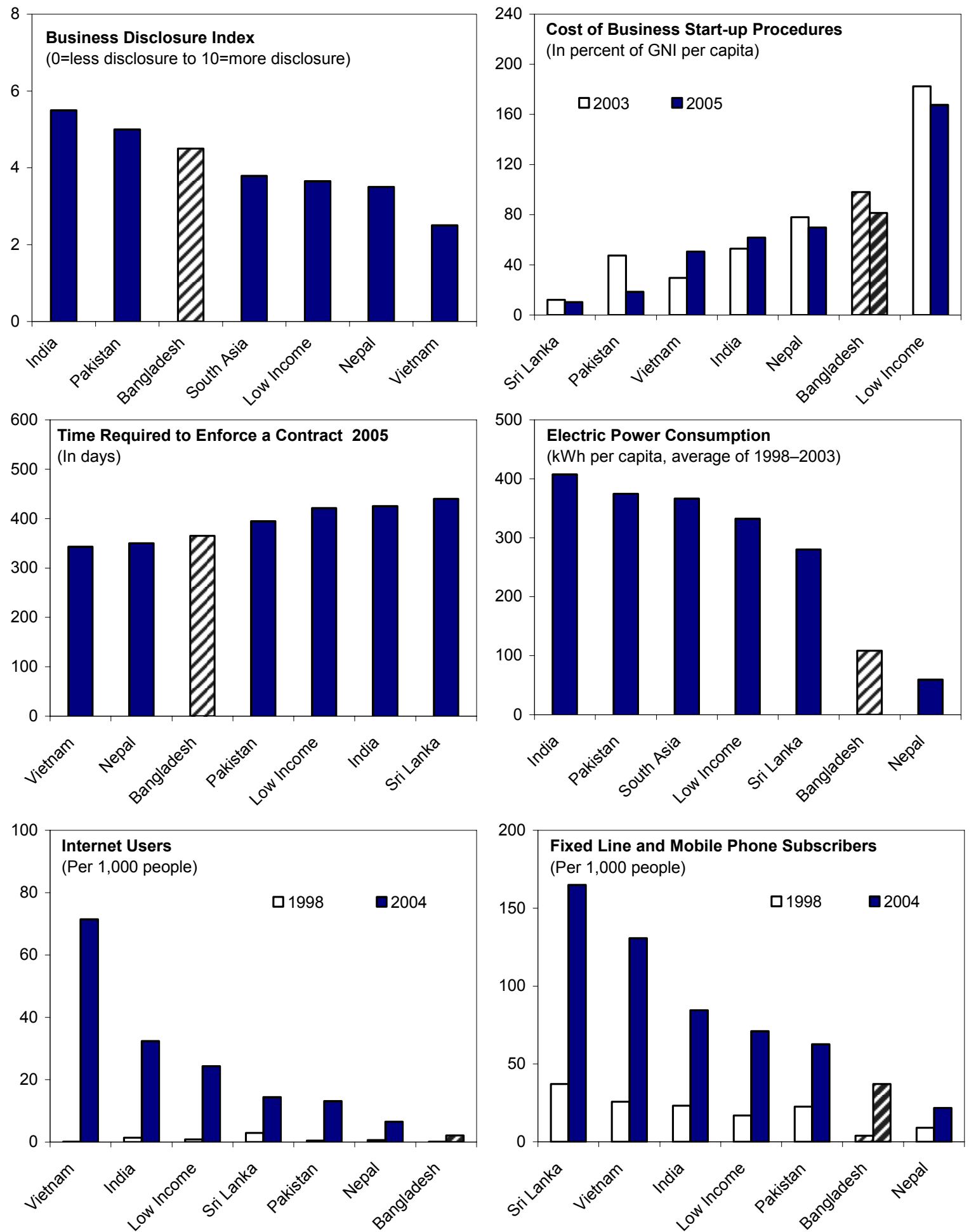

Source: World Bank Development Indicators. 
Figure 3. Bangladesh: Comparative Social Indicators
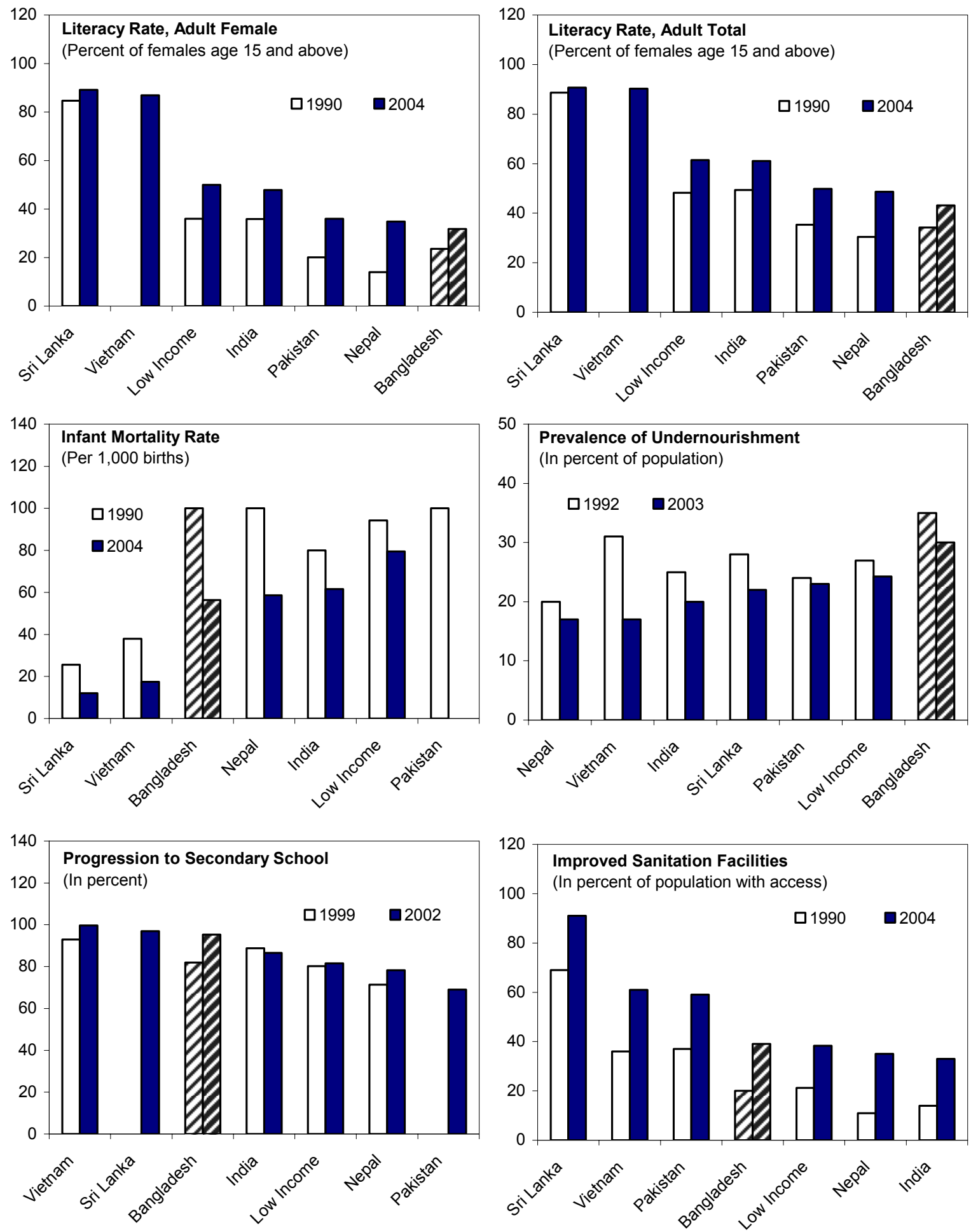

Source: World Bank Development Indicators. 
Table 1. Bangladesh: Key Economic Indicators, FY03-13 1/

\begin{tabular}{|c|c|c|c|c|c|c|c|c|c|c|c|}
\hline & \multirow[b]{2}{*}{ FY03 } & \multirow[b]{2}{*}{ FY04 } & \multirow[b]{2}{*}{ FY05 } & \multirow[b]{2}{*}{ FY06 } & \multicolumn{7}{|c|}{ Projection } \\
\hline & & & & & FY07 & FY08 & FY09 & FY10 & FY11 & FY12 & FY13 \\
\hline \multicolumn{12}{|l|}{ National income and prices (percent change) } \\
\hline Real GDP & 5.3 & 6.3 & 6.0 & 6.6 & 6.7 & 6.7 & 7.0 & 7.0 & 7.0 & 7.0 & 7.0 \\
\hline GDP deflator & 4.5 & 4.2 & 5.1 & 5.2 & 6.3 & 6.7 & 5.0 & 4.0 & 4.0 & 4.0 & 4.0 \\
\hline CPI inflation (annual average) 2/ & 4.4 & 5.8 & 6.5 & 7.2 & 7.2 & 6.5 & 5.0 & 4.0 & 4.0 & 4.0 & 4.0 \\
\hline \multicolumn{12}{|l|}{ Central government operations (percent of GDP) } \\
\hline Total revenue & 10.3 & 10.2 & 10.5 & 10.7 & 10.4 & 10.7 & 11.1 & 11.5 & 11.9 & 12.2 & 12.2 \\
\hline Tax & 8.3 & 8.2 & 8.5 & 8.5 & 8.3 & 8.6 & 9.0 & 9.4 & 9.8 & 10.1 & 10.1 \\
\hline Nontax & 2.0 & 1.9 & 2.0 & 2.2 & 2.1 & 2.1 & 2.1 & 2.1 & 2.1 & 2.1 & 2.1 \\
\hline Total expenditure & 13.7 & 13.3 & 13.8 & 13.9 & 14.0 & 15.9 & 14.3 & 14.8 & 15.4 & 15.8 & 15.8 \\
\hline Current expenditure & 8.1 & 7.8 & 8.4 & 8.4 & 9.0 & 8.8 & 8.6 & 8.6 & 8.6 & 8.5 & 8.5 \\
\hline Of which: Interest payments & 1.9 & 1.6 & 1.7 & 1.8 & 1.9 & 2.1 & 1.9 & 1.9 & 1.9 & 1.9 & 1.8 \\
\hline Of which: Subsidies & 2.3 & 2.4 & 2.8 & 2.6 & 3.0 & 2.8 & 2.8 & 2.8 & 2.8 & 2.8 & 2.8 \\
\hline Annual Development Program & 5.4 & 5.0 & 5.0 & 4.7 & 4.3 & 4.8 & 4.9 & 5.4 & 6.0 & 6.5 & 6.5 \\
\hline Other expenditures $3 /$ & 0.1 & 0.5 & 0.4 & 0.8 & 0.7 & 2.3 & 0.8 & 0.8 & 0.8 & 0.8 & 0.8 \\
\hline Overall balance (excluding grants) 4/ & -3.4 & -3.1 & -3.3 & -3.2 & -3.5 & -5.2 & -3.3 & -3.3 & -3.5 & -3.6 & -3.6 \\
\hline Primary balance 4/ & -1.5 & -1.4 & -1.7 & -1.4 & -1.6 & -3.1 & -1.3 & -1.4 & -1.6 & -1.8 & -1.8 \\
\hline Financing (net) & 3.4 & 3.1 & 3.3 & 3.2 & 3.5 & 5.2 & 3.3 & 3.3 & 3.5 & 3.6 & 3.6 \\
\hline Domestic 4/ 5/ & 1.2 & 1.8 & 1.7 & 2.1 & 2.3 & 3.7 & 1.7 & 1.6 & 1.6 & 1.6 & 1.6 \\
\hline External & 2.1 & 1.3 & 1.6 & 1.2 & 1.2 & 1.5 & 1.6 & 1.7 & 1.9 & 2.0 & 2.0 \\
\hline Total central government debt (percent of GDP) & 51.1 & 51.0 & 50.1 & 49.3 & 46.9 & 46.4 & 44.6 & 43.1 & 41.9 & 40.8 & 39.8 \\
\hline \multicolumn{12}{|l|}{ Money and credit (end of fiscal year; percent change) } \\
\hline Net domestic assets & 12.2 & 13.5 & 17.1 & 19.6 & 13.4 & 14.2 & 16.0 & 14.2 & 14.7 & 15.0 & 15.4 \\
\hline Credit to private sector & 12.6 & 17.5 & 17.0 & 18.3 & 15.1 & 14.5 & 14.3 & 13.5 & 14.4 & 14.8 & 15.5 \\
\hline Broad money (M2) & 15.6 & 13.8 & 16.7 & 19.3 & 17.5 & 15.0 & 17.7 & 15.7 & 15.3 & 14.8 & 14.3 \\
\hline \multicolumn{12}{|l|}{ Balance of payments (in billions of U.S. dollars) 6/ } \\
\hline Exports, f.o.b. & 6.5 & 7.5 & 8.6 & 10.4 & 12.5 & 15.0 & 17.1 & 19.5 & 22.1 & 25.1 & 28.5 \\
\hline (Annual percent change) & 9.5 & 15.9 & 14.0 & 21.6 & 19.9 & 19.9 & 14.1 & 14.1 & 13.4 & 13.5 & 13.6 \\
\hline Imports, f.o.b. & -8.7 & -9.8 & -11.9 & -13.3 & -16.0 & -19.3 & -21.8 & -24.4 & -27.4 & -30.7 & -34.5 \\
\hline (Annual percent change) & 13.1 & 13.0 & 20.6 & 12.1 & 20.0 & 21.2 & 12.7 & 12.1 & 12.0 & 12.1 & 12.4 \\
\hline Current account & 0.2 & 0.2 & -0.6 & 0.6 & 0.5 & 0.2 & -0.1 & -0.5 & -0.9 & -1.5 & -2.1 \\
\hline (Percent of GDP) & 0.3 & 0.3 & -0.9 & 0.9 & 0.8 & 0.3 & -0.2 & -0.5 & -1.0 & -1.4 & -1.8 \\
\hline Gross official reserves (in billions of U.S. dollars) & 2.5 & 2.7 & 2.9 & 3.5 & 5.0 & 5.7 & 6.9 & 8.1 & 9.2 & 10.2 & 10.8 \\
\hline In months of imports of goods and nonfactor services & 2.9 & 2.8 & 2.5 & 2.7 & 3.2 & 3.0 & 3.2 & 3.4 & 3.4 & 3.4 & 3.2 \\
\hline \multicolumn{12}{|l|}{ Memorandum item: } \\
\hline Nominal GDP (in billions of taka) & 3,006 & 3,330 & 3,707 & 4,157 & 4,715 & 5,368 & 6,031 & 6,712 & 7,469 & 8,311 & 9,249 \\
\hline
\end{tabular}

Sources: Data provided by the Bangladesh authorities; and Fund staff estimates and projections.

1/ Fiscal year begins July 1.

2/ CPI uses FY96 weights.

$3 /$ Consists of other capital, net lending, food account balances, check float and discrepancy.

4/ Includes assumption of BPC liabilities of 1.6 percent of GDP in FY08.

$5 /$ Includes estimated privatization receipts of 0.5 percent of GDP in FY07.

6 / Balance of payments is presented on the basis of BPM5. 
Table 2. Bangladesh: Balance of Payments, FY05-13 1/

(In millions of U.S. dollars, unless otherwise indicated)

\begin{tabular}{|c|c|c|c|c|c|c|c|c|c|c|}
\hline & \multirow[t]{2}{*}{ FY05 } & \multirow{2}{*}{$\frac{\text { FY06 }}{\text { Est. }}$} & \multicolumn{2}{|c|}{ FY07 } & \multirow[t]{2}{*}{ FY08 } & \multirow[t]{2}{*}{ FY09 } & \multirow[t]{2}{*}{ FY10 } & \multirow[t]{2}{*}{ FY11 } & \multirow[t]{2}{*}{ FY12 } & \multirow[t]{2}{*}{ FY13 } \\
\hline & & & CR 06/406 & Proj. & & & & & & \\
\hline Trade balance & $-3,297$ & $-2,879$ & $-3,426$ & $-3,457$ & $-4,350$ & $-4,693$ & $-4,915$ & $-5,246$ & $-5,573$ & $-5,943$ \\
\hline Exports (f.o.b.) & 8,573 & 10,422 & 12,003 & 12,499 & 14,989 & 17,096 & 19,507 & 22,118 & 25,111 & 28,534 \\
\hline Of which: RMG sector & 6,432 & 7,901 & 9,167 & 9,484 & 11,665 & 13,415 & 15,427 & 17,586 & 20,049 & 22,855 \\
\hline Imports (f.o.b) & $-11,870$ & $-13,301$ & $-15,429$ & $-15,955$ & $-19,339$ & $-21,789$ & $-24,422$ & $-27,364$ & $-30,684$ & $-34,477$ \\
\hline Of which: Crude petroleum and petroleum products & $-1,602$ & $-2,004$ & $-2,324$ & $-2,156$ & $-2,426$ & $-2,674$ & $-2,873$ & $-3,090$ & $-3,324$ & $-3,603$ \\
\hline Services & -870 & $-1,110$ & $-1,385$ & $-1,441$ & $-1,981$ & $-2,348$ & $-2,745$ & $-3,193$ & $-3,705$ & $-4,298$ \\
\hline Income & -680 & -786 & -929 & -899 & $-1,007$ & $-1,048$ & $-1,152$ & $-1,271$ & $-1,404$ & $-1,554$ \\
\hline Transfers & 4,290 & 5,347 & 6,033 & 6,332 & 7,531 & 7,951 & 8,349 & 8,767 & 9,200 & 9,656 \\
\hline Official current transfers $2 /$ & 37 & 34 & 51 & 78 & 70 & 43 & 45 & 47 & 50 & 53 \\
\hline Private transfers & 4,253 & 5,313 & 5,982 & 6,254 & 7,461 & 7,909 & 8,304 & 8,719 & 9,151 & 9,604 \\
\hline Of which: Workers' remittances & 3,848 & 4,802 & 5,585 & 5,954 & 7,086 & 7,511 & 7,887 & 8,281 & 8,695 & 9,130 \\
\hline Current account balance & -557 & 572 & 293 & 536 & 192 & -138 & -463 & -944 & $-1,482$ & $-2,139$ \\
\hline Capital and financial account balance & 624 & -207 & 312 & 894 & 408 & 1,312 & 1,767 & 2,129 & 2,543 & 2,854 \\
\hline Capital account & 163 & 242 & 250 & 214 & 483 & 517 & 595 & 690 & 814 & 952 \\
\hline Financial account & 461 & -449 & 62 & 680 & -75 & 795 & 1,172 & 1,440 & 1,730 & 1,902 \\
\hline Foreign direct investment & 800 & 675 & 730 & 700 & 750 & 842 & 916 & 1,000 & 1,091 & 1,190 \\
\hline Portfolio investment & 0 & 32 & 20 & 30 & 25 & 0 & 0 & 0 & 0 & 0 \\
\hline Net aid flows $3 /$ & 491 & 432 & 469 & 533 & 583 & 755 & 916 & 1,163 & 1,360 & 1,431 \\
\hline Aid disbursements & 940 & 921 & 933 & 1,029 & 1,101 & 1,377 & 1,596 & 1,873 & 2,102 & 2,194 \\
\hline Debt amortization & -449 & -489 & -464 & -496 & -518 & -622 & -681 & -710 & -742 & -762 \\
\hline Other capital $4 /$ & -830 & $-1,588$ & $-1,157$ & -582 & $-1,434$ & -801 & -659 & -723 & -722 & -719 \\
\hline Overall balance & 67 & 365 & 200 & 1,430 & 600 & 1,174 & 1,303 & 1,185 & 1,062 & 715 \\
\hline Financing items & -67 & -365 & -200 & $-1,430$ & -600 & $-1,174$ & $-1,303$ & $-1,185$ & $-1,062$ & -715 \\
\hline Bangladesh Bank & -67 & -365 & -200 & $-1,430$ & -600 & $-1,174$ & $-1,303$ & $-1,185$ & $-1,062$ & -715 \\
\hline Assets (- increase) & -225 & -554 & -311 & $-1,530$ & -690 & $-1,159$ & $-1,266$ & $-1,130$ & -971 & -619 \\
\hline Liabilities $5 /$ & 158 & 189 & 111 & 100 & 90 & -15 & -37 & -55 & -91 & -96 \\
\hline \multicolumn{11}{|l|}{ Memorandum items: } \\
\hline Current account balance (percent of GDP) & -0.9 & 0.9 & 0.4 & 0.8 & 0.3 & -0.2 & -0.5 & -1.0 & -1.4 & -1.8 \\
\hline Export growth rate (percent) & 14.0 & 21.6 & 15.2 & 19.9 & 19.9 & 14.1 & 14.1 & 13.4 & 13.5 & 13.6 \\
\hline Import growth rate (percent) & 20.6 & 12.1 & 16.0 & 20.0 & 21.2 & 12.7 & 12.1 & 12.0 & 12.1 & 12.4 \\
\hline Gross official reserves (in millions of U.S. dollars) & 2,930 & 3,471 & 3,831 & 5,001 & 5,691 & 6,850 & 8,116 & 9,246 & 10,217 & 10,836 \\
\hline (In months of imports of goods and services) & 2.5 & 2.7 & 2.5 & 3.2 & 3.0 & 3.2 & 3.4 & 3.4 & 3.4 & 3.2 \\
\hline Net international reserves (in millions of U.S. dollars) & 2,046 & 2,221 & 2,421 & 3,651 & 4,251 & 5,425 & 6,728 & 7,913 & 8,975 & 9,690 \\
\hline Medium and long-term external public debt (in millions of U.S. dollars) & 19,286 & 19,266 & $\ldots$ & 19,799 & 20,382 & 21,137 & 22,052 & 23,215 & 24,575 & 26,007 \\
\hline (In percent of GDP) & 32.0 & 31.1 & $\ldots$ & 29.0 & 26.9 & 25.5 & 24.4 & 23.4 & 22.6 & 21.8 \\
\hline Net aid flows/GDP (in percent) & 1.1 & 1.1 & 1.2 & 1.2 & 1.5 & 1.6 & 1.7 & 1.9 & 2.0 & 2.0 \\
\hline Nominal GDP (in millions of U.S. dollars) & 60,299 & 61,952 & 66,504 & 68,337 & 75,814 & 82,827 & 90,542 & 99,128 & 108,591 & 119,093 \\
\hline
\end{tabular}

Sources: Data provided by the Bangladesh authorities; and Fund staff estimates and projections.

$1 /$ Fiscal year begins July 1 .

2/ Excludes official capital grants.

3/ Loans only. For FY05 includes flood-related donor assistance of US\$123 million, plus World Bank loans (DSC II and education) totaling another US $\$ 300$ million that were originally planned for FY04.

4/ Includes trade credits, long-term borrowing, short-term financing for BPC, commercial bank net borrowing, and errors and omissions.

$5 /$ Includes Asian Clearing Union balances. 
Table 3. Bangladesh: Central Government Operations, FY2005-13 1/

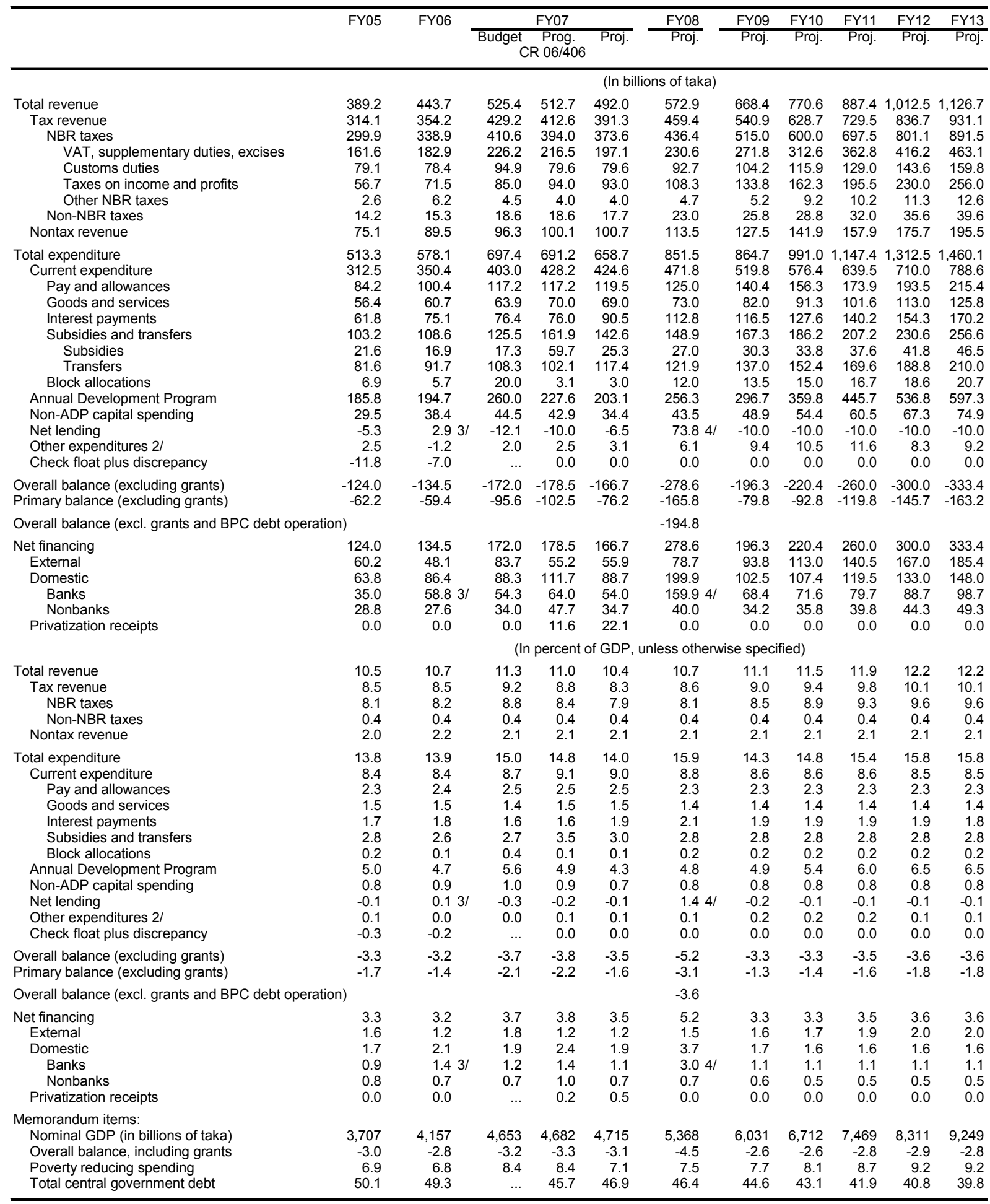

Sources: Data provided by the Bangladesh authorities; and Fund staff estimates and projections.

1/ Fiscal year ends June 30. Cash basis unless otherwise specified.

$2 /$ Include food account surplus(-)/deficit(+) and extraordinary expenditures.

3 / Includes bonds ( 10 billion taka) issued to a nationalized commercial bank to assume BPC's liabilities.

4 / Includes bonds (84 billion taka) issued to three nationalized commercial banks to assume BPC's liabilities. 
Table 4. Bangladesh: Central Bank Balance Sheet, June 2006-June 2008

\begin{tabular}{|c|c|c|c|c|c|c|c|c|c|c|c|c|c|c|}
\hline & \multicolumn{2}{|c|}{ Jun-06 } & \multicolumn{2}{|c|}{ Sep-06 } & \multicolumn{2}{|c|}{ Dec-06 } & \multicolumn{2}{|c|}{ Mar-07 } & \multicolumn{2}{|c|}{ Jun-07 } & \multirow{2}{*}{$\frac{\text { Sep-07 }}{\text { Proj. }}$} & \multirow{2}{*}{$\frac{\text { Dec-07 }}{\text { Proj. }}$} & \multirow{2}{*}{$\frac{\text { Mar-08 }}{\text { Proj. }}$} & \multirow{2}{*}{$\frac{\text { Jun-08 }}{\text { Proj. }}$} \\
\hline & Rev. Prog. & $\overline{\text { Actual }}$ & Prog. & Actual & Prog. & Actual & Prog. & Actual & Prog. & Est. & & & & \\
\hline & \multicolumn{14}{|c|}{ (End of period; in billions of taka) } \\
\hline Net international reserves $1 /$ & 140 & 155 & 153 & 152 & 155 & 171 & 156 & 199 & 172 & 252 & 265 & 278 & 292 & 305 \\
\hline Net international reserves $2 /$ & $\ldots$ & 153 & 153 & 155 & 153 & 165 & 153 & 192 & 167 & 246 & $\ldots$ & $\ldots$ & $\ldots$ & $\ldots$ \\
\hline Net international reserves $3 /$ & $\ldots$ & $\ldots$ & $\ldots$ & $\ldots$ & $\ldots$ & $\ldots$ & $\ldots$ & 199 & $\ldots$ & 251 & 261 & 272 & 282 & 292 \\
\hline Net domestic assets $1 /$ & 178 & 185 & 207 & 206 & 214 & 245 & 216 & 192 & 214 & 143 & 149 & 152 & 155 & 145 \\
\hline Net domestic assets $2 /$ & $\ldots$ & 186 & 207 & 203 & 216 & 252 & 219 & 199 & 219 & 149 & $\ldots$ & $\ldots$ & $\ldots$ & $\ldots$ \\
\hline Net domestic assets $3 /$ & $\ldots$ & $\ldots$ & $\ldots$ & $\ldots$ & $\ldots$ & $\ldots$ & $\ldots$ & 192 & $\ldots$ & 144 & 153 & 158 & 165 & 157 \\
\hline Net credit to central government & 170 & 237 & 201 & 222 & 203 & 258 & 211 & 225 & 220 & 188 & 196 & 199 & 204 & 194 \\
\hline Credit to other nonfinancial public sector & 1 & 0 & 0 & 0 & 0 & 0 & 0 & 0 & 0 & 0 & 0 & 0 & 0 & 0 \\
\hline Credit to deposit money banks & 61 & 60 & 63 & 60 & 65 & 60 & 66 & 60 & 66 & 62 & 61 & 61 & 61 & 61 \\
\hline Other items, net $1 /$ & -49 & -111 & -58 & -76 & -54 & -72 & -61 & -93 & -72 & -107 & -108 & -109 & -110 & -111 \\
\hline Reserve money & 318 & 340 & 360 & 358 & 369 & 417 & 372 & 391 & 386 & 395 & 414 & 430 & 447 & 450 \\
\hline Currency & 229 & 249 & 268 & 259 & 277 & 318 & 276 & 283 & 288 & 296 & 311 & 322 & 335 & 337 \\
\hline \multirow[t]{2}{*}{ Reserves } & 89 & 90 & 92 & 98 & 92 & 98 & 96 & 107 & 99 & 99 & 104 & 108 & 112 & 112 \\
\hline & \multicolumn{14}{|c|}{ (Change since start of fiscal year; in billions of taka) } \\
\hline Net international reserves $1 /$ & 10 & 24 & -2 & -3 & 0 & 16 & 1 & 44 & 17 & 97 & 13 & 26 & 40 & 53 \\
\hline Net international reserves $2 /$ & $\ldots$ & $\ldots$ & 0 & 2 & 0 & 11 & 0 & 39 & 14 & 93 & $\ldots$ & $\ldots$ & $\ldots$ & $\ldots$ \\
\hline Net international reserves $3 /$ & $\ldots$ & $\ldots$ & $\ldots$ & $\ldots$ & $\ldots$ & $\ldots$ & $\ldots$ & $\ldots$ & $\ldots$ & $\ldots$ & 10 & 21 & 31 & 41 \\
\hline Net domestic assets $1 /$ & 34 & 41 & 22 & 22 & 30 & 61 & 31 & 7 & 30 & -41 & 6 & 9 & 12 & 1 \\
\hline Net domestic assets $2 /$ & $\ldots$ & $\ldots$ & 20 & 17 & 29 & 66 & 32 & 13 & 33 & -37 & $\ldots$ & $\ldots$ & $\ldots$ & $\ldots$ \\
\hline Net domestic assets $3 /$ & $\ldots$ & $\ldots$ & $\ldots$ & $\ldots$ & $\ldots$ & $\ldots$ & $\ldots$ & $\ldots$ & $\ldots$ & $\ldots$ & 9 & 14 & 21 & 13 \\
\hline Net credit to central government & 23 & 92 & -35 & -14 & -34 & 21 & -26 & -12 & -17 & -48 & 8 & 11 & 15 & 6 \\
\hline Credit to other nonfinancial public sector & 1 & 0 & 0 & 0 & 0 & 0 & 0 & 0 & 0 & 0 & 0 & 0 & 0 & 0 \\
\hline Credit to deposit money banks & 4 & 2 & 4 & 1 & 6 & 0 & 6 & 0 & 7 & 2 & -1 & -1 & -1 & -1 \\
\hline Other items, net $1 /$ & 11 & -52 & 53 & 35 & 57 & 39 & 50 & 18 & 39 & 4 & -1 & -2 & -3 & -4 \\
\hline Reserve money & 44 & 66 & 20 & 19 & 29 & 77 & 32 & 51 & 47 & 55 & 19 & 35 & 52 & 55 \\
\hline Currency & 26 & 46 & 19 & 10 & 28 & 69 & 27 & 34 & 39 & 47 & 14 & 26 & 39 & 41 \\
\hline Reserves & 19 & 20 & 2 & 8 & 1 & 8 & 6 & 17 & 9 & 9 & 5 & 9 & 13 & 14 \\
\hline \multicolumn{15}{|l|}{ Memorandum items: } \\
\hline Reserve money (year-on-year percent change) & 16.0 & 23.9 & 28.5 & 27.8 & 18.4 & 33.7 & 18.4 & 24.4 & 13.8 & 16.3 & 15.7 & 3.2 & 14.3 & 13.8 \\
\hline Net international reserves (in millions of U.S. dollars) 1/ & 2,058 & 2,221 & 2,221 & 2,253 & 2,221 & 2,478 & 2,221 & 2,894 & 2,421 & 3,650 & 3,800 & 3,950 & 4,100 & 4,250 \\
\hline Flow since start of fiscal year (in millions of U.S. dollars) 1/ & 11 & 176 & 0 & 32 & 0 & 256 & 0 & 672 & 200 & 1,428 & 150 & 300 & 450 & 600 \\
\hline Net international reserves (in millions of U.S. dollars) 2/ & $\ldots$ & 2,140 & 2,140 & 2,163 & 2,140 & 2,300 & 2,140 & 2,683 & 2,340 & 3,439 & $\ldots$ & $\ldots$ & $\ldots$ & $\ldots$ \\
\hline Flow since start of fiscal year (in millions of U.S. dollars) 2/ & $\ldots$ & $\ldots$ & 0 & 23 & 0 & 160 & 0 & 543 & 200 & 1,299 & $\ldots$ & $\ldots$ & $\ldots$ & $\ldots$ \\
\hline Net international reserves (in millions of U.S. dollars) 3/ & $\ldots$ & $\ldots$ & $\ldots$ & $\ldots$ & $\ldots$ & $\ldots$ & $\ldots$ & 2,894 & $\ldots$ & 3,650 & 3,800 & 3,950 & 4,100 & 4,250 \\
\hline Flow since start of fiscal year (in millions of U.S. dollars) $3 /$ & $\ldots$ & $\ldots$ & $\ldots$ & $\ldots$ & $\ldots$ & $\ldots$ & $\ldots$ & $\ldots$ & $\ldots$ & $\ldots$ & 150 & 300 & 450 & 600 \\
\hline Required domestic cash reserves (in billions of taka) & 81 & 86 & 88 & 88 & 88 & 93 & 93 & 95 & 96 & 96 & 100 & 106 & 105 & 111 \\
\hline Excess domestic cash reserves (in billions of taka) & 8 & 4 & 3 & 10 & 3 & 5 & 3 & 12 & 3 & 2 & 4 & 1 & 6 & 2 \\
\hline
\end{tabular}

Sources: Data provided by the Bangladesh authorities; and Fund staff estimates and projections.

1/ Calculated from monetary data using end-of-period exchange rates.

2/ Calculated using program exchange rates (rates for FY07 as of end-March 2006).

3 / Calculated using program exchange rates (rates for FY08 as of end-March 2007). 
Table 5. Bangladesh: Monetary Survey, June 2006-June 2008

\begin{tabular}{|c|c|c|c|c|c|c|c|c|c|c|c|c|c|c|}
\hline & \multicolumn{2}{|c|}{ Jun-06 } & \multicolumn{2}{|c|}{ Sep-06 } & \multicolumn{2}{|c|}{ Dec-06 } & \multicolumn{2}{|c|}{ Mar-07 } & \multicolumn{2}{|c|}{ Jun-07 } & \multirow{2}{*}{$\frac{\text { Sep-07 }}{\text { Proj. }}$} & \multirow{2}{*}{$\frac{\text { Dec-07 }}{\text { Proj. }}$} & \multirow{2}{*}{$\frac{\text { Mar-08 }}{\text { Proj. }}$} & \multirow{2}{*}{$\begin{array}{r}\text { Jun-08 } \\
\text { Proj. }\end{array}$} \\
\hline & Rev. Prog. & $\overline{\text { Actual }}$ & Prog. & $\overline{\text { Actual }}$ & Prog. & Actual & Prog. & ctual & Prog. & Proj. & & & & \\
\hline & \multicolumn{14}{|c|}{ (End of period; in billions of taka) } \\
\hline Net foreign assets & 203 & 218 & 220 & 223 & 227 & 251 & 234 & 269 & 255 & 322 & 336 & 356 & 370 & 385 \\
\hline Net domestic assets & 1,528 & 1,588 & 1,653 & 1,640 & 1,687 & 1,760 & 1,714 & 1,741 & 1,817 & 1,801 & 1,857 & 1,986 & 1,951 & 2,056 \\
\hline Domestic credit & 1,675 & 1,732 & 1,797 & 1,797 & 1,831 & 1,901 & 1,864 & 1,905 & 1,975 & 1,981 & 2,039 & 2,168 & 2,121 & 2,254 \\
\hline Net credit to central government & 302 & 296 & 296 & 320 & 300 & 347 & 316 & 326 & 360 & 350 & 465 & 496 & 513 & 510 \\
\hline Credit to other nonfinancial public sector & 112 & 127 & 127 & 130 & 127 & 131 & 127 & 126 & 123 & 123 & 34 & 28 & 23 & 18 \\
\hline Credit to private sector & 1,261 & 1,309 & 1,374 & 1,347 & 1,404 & 1,423 & 1,422 & 1,453 & 1,492 & 1,507 & 1,540 & 1,644 & 1,585 & 1,726 \\
\hline Other items, net & -147 & -144 & -144 & -157 & -144 & -141 & -150 & -164 & -158 & -180 & -182 & -182 & -170 & -197 \\
\hline \multirow[t]{2}{*}{ Broad money (M2) } & 1,730 & 1,806 & 1,873 & 1,863 & 1,914 & 2,010 & 1,948 & 2,010 & 2,072 & 2,122 & 2,193 & 2,342 & 2,322 & 2,442 \\
\hline & \multicolumn{14}{|c|}{ (Change since start of fiscal year; in billions of taka) } \\
\hline Net foreign assets & 17 & 32 & 2 & 5 & 9 & 33 & 16 & 51 & 37 & 104 & 15 & 34 & 49 & 63 \\
\hline Net domestic assets & 199 & 260 & 64 & 52 & 99 & 171 & 126 & 153 & 229 & 212 & 56 & 186 & 151 & 256 \\
\hline Domestic credit & 242 & 301 & 65 & 65 & 99 & 169 & 132 & 173 & 243 & 249 & 58 & 188 & 141 & 273 \\
\hline Net credit to central government & 63 & 59 & 0 & 24 & 4 & 51 & 20 & 30 & 64 & 54 & 115 & 146 & 163 & 160 \\
\hline Credit to other nonfinancial public sector & 25 & 40 & 0 & 3 & 0 & 4 & 0 & 0 & -4 & -4 & -89 & -95 & -100 & -105 \\
\hline Credit to private sector & 154 & 202 & 65 & 38 & 95 & 114 & 113 & 144 & 183 & 198 & 33 & 138 & 78 & 219 \\
\hline Other items, net & -43 & -41 & 0 & -13 & 0 & 2 & -6 & -21 & -14 & -36 & -2 & -2 & 10 & -17 \\
\hline \multirow[t]{2}{*}{ Broad money (M2) } & 216 & 292 & 67 & 57 & 108 & 204 & 142 & 204 & 266 & 316 & 71 & 220 & 199 & 319 \\
\hline & \multicolumn{14}{|c|}{ (Year-on-year percent change) } \\
\hline Net foreign assets & 9.2 & 17.2 & 22.1 & 23.8 & 22.5 & 35.4 & 19.2 & 37.3 & 17.0 & 47.7 & 50.9 & 41.8 & 37.7 & 19.7 \\
\hline Net domestic assets & 15.0 & 19.6 & 20.1 & 19.2 & 15.6 & 20.5 & 15.5 & 17.3 & 14.4 & 13.4 & 13.2 & 12.9 & 12.1 & 14.2 \\
\hline Domestic credit & 16.9 & 21.1 & 20.2 & 20.2 & 16.6 & 21.0 & 15.1 & 17.6 & 14.1 & 14.4 & 13.4 & 14.1 & 11.3 & 13.8 \\
\hline Net credit to central government & 26.5 & 24.8 & 20.0 & 29.9 & 18.5 & 37.0 & 28.0 & 32.2 & 21.5 & 18.2 & 45.3 & 42.8 & 57.3 & 45.6 \\
\hline Credit to other nonfinancial public sector & 29.4 & 46.7 & 22.2 & 25.1 & 1.0 & 4.2 & -0.1 & -0.4 & -2.8 & -2.8 & -73.8 & -78.6 & -81.8 & -85.4 \\
\hline Credit to private sector & 13.9 & 18.3 & 20.0 & 17.7 & 17.8 & 19.4 & 14.1 & 16.6 & 14.0 & 15.1 & 14.3 & 15.6 & 9.1 & 14.5 \\
\hline Other items, net & 41.5 & 40.2 & 21.5 & 32.2 & 30.5 & 28.2 & 10.5 & 21.0 & 10.1 & 25.4 & 16.2 & 28.6 & 3.5 & 9.6 \\
\hline \multirow[t]{2}{*}{ Broad money (M2) } & 14.3 & 19.3 & 20.3 & 19.7 & 16.3 & 22.2 & 16.0 & 19.7 & 14.7 & 17.5 & 17.7 & 16.5 & 15.5 & 15.0 \\
\hline & \multicolumn{14}{|c|}{ (In billions of taka, unless otherwise noted) } \\
\hline \multicolumn{15}{|l|}{ Memorandum items: } \\
\hline Broad money multiplier & 5.44 & 5.32 & 5.20 & 5.20 & 5.19 & 4.83 & 5.24 & 5.16 & 5.36 & 5.37 & 5.29 & 5.45 & 5.20 & 5.43 \\
\hline Broad money velocity & 2.40 & 2.30 & 2.28 & 2.31 & 2.30 & 2.21 & 2.33 & 2.28 & 2.26 & 2.22 & 2.22 & 2.15 & 2.24 & 2.20 \\
\hline Net domestic financing (since beginning of $\mathrm{FY}$ ) & 83 & 86 & 12 & 34 & 25 & 66 & 49 & 62 & 112 & 89 & 125 & 166 & 193 & 200 \\
\hline Bank & 63 & 59 & 0 & 24 & 4 & 51 & 20 & 30 & 64 & 54 & 115 & 146 & 163 & 160 \\
\hline Nonbanks & 20 & 28 & 12 & 10 & 21 & 15 & 29 & 33 & 48 & 35 & 10 & 20 & 30 & 40 \\
\hline
\end{tabular}

Sources: Data provided by the Bangladesh authorities; and Fund staff estimates and projections. 
Table 6. Bangladesh: Indicative Targets and Quantitative Performance Criteria Under the PRGF Arrangement, June 2006-2007 1/

(Cumulative flows, end of period) 21

\begin{tabular}{|c|c|c|c|c|c|c|c|c|c|}
\hline $\begin{array}{r}\text { Jur } \\
\text { Indicativ } \\
\end{array}$ & argets & $\begin{array}{r}\text { Sept } \\
\text { Indicative }\end{array}$ & $\begin{array}{l}6 \\
\text { argets }\end{array}$ & $\begin{array}{r}\text { Dec } \\
\text { Performanc }\end{array}$ & Criteria & $\begin{array}{r}\text { Mar } \\
\text { Indicative }\end{array}$ & argets & $\begin{array}{c}\text { Jun } \\
\text { Indicative T }\end{array}$ & \\
\hline Rev. Prog. & Actual & Target & Actual & Target & Actual & Target & Actual & Target 3/ & Proj. \\
\hline
\end{tabular}

Ceiling on net domestic assets of Bangladesh Bank 4/ 5/ 6/

Ceiling on net domestic financing of central government $4 / 5 /$

Floor on total revenue of the central government $7 /$

Floor on cumulative increase of net international reserves of Bangladesh Bank 4/ 5/ 6/ 8/

Contracting or guaranteeing of short-term external debt

by the central government $9 / 10 /$

Contracting or guaranteeing of nonconcessional medium-

and long-term debt by the central government $4 / 11 /$

Of which: External debt with an initial maturity of over one year and up to five years $9 /$

Accumulation of external payments arrears $9 /$

$\begin{array}{rrrr}44 & 59 & 20 & 17 \\ 83 & 86 & 12 & 34 \\ 356 & 339 & 105 & 108\end{array}$

(In billions of taka)

$\begin{array}{ccrrrr}27 & 66 & 30 & 13 & -37 & \ldots \\ 23 & 66 & 47 & 62 & 89 & \ldots \\ 221 & 211 & 342 & 328 & 492 & \ldots\end{array}$

(In millions of U.S. dollars)

\begin{tabular}{rrrrrrrrrr}
0 & 106 & 0 & 23 & 31 & 160 & 31 & 543 & 1299 & $\ldots$ \\
0 & $\ldots$ & 0 & 0 & 0 & 0 & 0 & 0 & 0 & $\ldots$ \\
250 & $\ldots$ & 100 & 0 & 150 & 0 & 200 & 0 & 250 & $\ldots$ \\
0 & $\ldots$ & 0 & 0 & 0 & 0 & 0 & 0 & 0 & $\ldots$ \\
0 & $\ldots$ & 0 & 0 & 0 & 0 & 0 & 0 & 0 & $\ldots$ \\
\hline
\end{tabular}

Sources: Data provided by the Bangladesh authorities; and Fund staff estimates and projections.

1/ The aggregates are defined in the Technical Memorandum of Understanding dated January 9, 2006.

2/ Cumulative flow since start of financial year beginning July 1.

3/ Targets for end-June 2007 will be monitored outside of the PRGF-supported program that will expire on June 19, 2007.

4/ Performance criteria assessed on a periodic basis under the program period.

$5 /$ Targets for FY07 are subject to an adjustor depending on the magnitude and timing of the World Bank's DSC (currently expected to be worth US $\$ 200$ million and

to be disbursed in the fourth quarter of FY07) and other budgetary support. Targets have been adjusted for AsDB budget support of $\$ 30.69$ (Tk2.195 billion

at the program exchange rate) disbursed on December 10, 2006.

6/ Targets for FY07 are subject to an adjustor depending on the magnitude of net foreign exchange receipts from the Rupali divestment.

7/ Assessed on quarterly basis as indicative targets for September 2005 and December 2005; and as a performance criterion from March 2006. Before July 2006, the target

referred to NBR taxes only.

8/ Adjusted downward by $\$ 100$ million for September and December 2005 and March 2006, reflecting delay in disbursement of World Bank education sector loan as per TMU

(IMF Country Report No. 05/241).

9/ Performance criteria assessed on a continuous basis under the program period.

10/ The target excludes import-related credits, forward contracts, swaps, other future market contracts, and short-term liabilities by the banking system.

11/ The target excludes credits extended by the Fund and Asian Development Bank, and U.S. Dollar Premium and Investment Bonds purchased by nonresidents. 
Table 7. Bangladesh: Financial System Structure, 1999-2006

(end-December)

\begin{tabular}{|c|c|c|c|c|c|c|c|c|}
\hline & 1999 & 2000 & 2001 & 2002 & 2003 & 2004 & 2005 & 2006 \\
\hline \multicolumn{9}{|l|}{ Structure of the financial system (number) } \\
\hline Banks & 39 & 49 & 51 & 50 & 50 & 49 & 48 & 48 \\
\hline Nationalized commercial banks & 4 & 4 & 4 & 4 & 4 & 4 & 4 & 4 \\
\hline Specialized development banks & 5 & 5 & 5 & 5 & 5 & 5 & 5 & 5 \\
\hline Private commercial banks & 17 & 30 & 30 & 30 & 30 & 30 & 30 & 30 \\
\hline Foreign commercial banks & 13 & 10 & 12 & 11 & 11 & 10 & 9 & 9 \\
\hline Insurance companies & 32 & $\ldots$ & 62 & $\ldots$ & $\ldots$ & $\ldots$ & 62 & $\ldots$ \\
\hline Life & 7 & $\ldots$ & 18 & $\ldots$ & $\ldots$ & $\ldots$ & 44 & $\ldots$ \\
\hline Non-life & 25 & $\ldots$ & 44 & $\ldots$ & $\ldots$ & $\ldots$ & 18 & $\ldots$ \\
\hline Finance companies & 19 & $\ldots$ & 26 & $\ldots$ & $\ldots$ & $\ldots$ & 28 & $\ldots$ \\
\hline Microfinance institutions & $\ldots$ & $\cdots$ & 624 & $\ldots$ & $\ldots$ & $\ldots$ & $1,000+$ & $\ldots$ \\
\hline \multicolumn{9}{|l|}{ Financial system assets (in billions of taka) } \\
\hline Banks & $\ldots$ & $\ldots$ & 1,444 & 1,538 & 1,636 & 1,913 & 2,254 & 2,589 \\
\hline Nationalized commercial banks & $\ldots$ & $\ldots$ & 635 & 716 & 701 & 771 & 849 & 875 \\
\hline Specialized development banks & $\ldots$ & $\ldots$ & 141 & 114 & 100 & 127 & 141 & 156 \\
\hline Private commercial banks & $\ldots$ & $\ldots$ & 495 & 557 & 658 & 844 & 1,033 & 1,285 \\
\hline Foreign commercial banks & $\ldots$ & $\ldots$ & 174 & 152 & 177 & 172 & 231 & 272 \\
\hline Insurance companies & $\ldots$ & $\ldots$ & 36 & $\ldots$ & $\ldots$ & $\ldots$ & $\ldots$ & $\ldots$ \\
\hline Life & $\ldots$ & $\ldots$ & 23 & $\ldots$ & $\ldots$ & $\ldots$ & $\ldots$ & $\ldots$ \\
\hline Non-life & $\ldots$ & $\ldots$ & 13 & $\ldots$ & $\ldots$ & $\ldots$ & $\ldots$ & $\ldots$ \\
\hline Non-bank financial institutions & $\ldots$ & $\ldots$ & 19 & $\ldots$ & $\ldots$ & $\ldots$ & $\ldots$ & $\ldots$ \\
\hline Microfinance institutions & $\ldots$ & $\ldots$ & 38 & 36 & 43 & 53 & 65 & $\ldots$ \\
\hline (as percent of private sector credit) & $\ldots$ & $\ldots$ & 5 & 5 & 5 & 5 & 5 & $\ldots$ \\
\hline Securities market capitalization (DSE) & 44 & 61 & 64 & 69 & 98 & 224 & 215 & 266 \\
\hline \multicolumn{9}{|l|}{ Market share of bank assets } \\
\hline Nationalized commercial banks & $\ldots$ & 71.7 & 44.8 & 47.1 & 43.9 & 41.6 & 39.0 & 35.3 \\
\hline Specialized development banks & $\ldots$ & $\ldots$ & 11.5 & 9.2 & 7.8 & 7.5 & 6.8 & 6.5 \\
\hline Private commercial banks & $\ldots$ & $\ldots$ & 32.8 & 34.7 & 38.5 & 42.5 & 44.4 & 48.2 \\
\hline Foreign commercial banks & $\ldots$ & 4.2 & 10.8 & 8.9 & 9.8 & 8.4 & 9.8 & 10.0 \\
\hline \multicolumn{9}{|l|}{ Bank asset concentration } \\
\hline Share of three largest banks in total loans (percent) & $\ldots$ & $\ldots$ & $\ldots$ & 38 & 35 & 33 & 33 & 33 \\
\hline $\begin{array}{l}\text { Share of three largest private banks in all private } \\
\text { bank loans }\end{array}$ & $\ldots$ & $\ldots$ & $\ldots$ & 29 & 27 & 26 & 27 & 26 \\
\hline \multicolumn{9}{|l|}{ Assets as percent of GDP } \\
\hline Banks & $\ldots$ & $\ldots$ & 54.8 & 53.6 & 51.6 & 54.4 & 57.2 & 58.2 \\
\hline Nationalized commercial banks & $\ldots$ & $\ldots$ & 24.1 & 24.9 & 22.1 & 21.9 & 21.5 & 19.7 \\
\hline Specialized development banks & $\ldots$ & $\ldots$ & 5.4 & 4.0 & 3.1 & 3.6 & 3.6 & 3.5 \\
\hline Private commercial banks & $\ldots$ & $\ldots$ & 18.8 & 19.4 & 20.8 & 24.0 & 26.2 & 28.9 \\
\hline Foreign commercial banks & $\ldots$ & $\ldots$ & 6.6 & 5.3 & 5.6 & 4.9 & 5.9 & 6.1 \\
\hline Insurance companies & $\ldots$ & $\ldots$ & 1.4 & $\ldots$ & $\ldots$ & $\ldots$ & $\ldots$ & $\ldots$ \\
\hline Finance companies & $\ldots$ & $\ldots$ & 0.7 & $\ldots$ & $\ldots$ & $\ldots$ & $\ldots$ & $\ldots$ \\
\hline Microfinance institutions & $\ldots$ & $\ldots$ & 1.4 & 1.3 & 1.4 & 1.5 & 1.6 & $\ldots$ \\
\hline Securities market capitalization (DSE) & 2.0 & 2.5 & 2.4 & 2.4 & 3.1 & 6.4 & 5.5 & 6.0 \\
\hline
\end{tabular}

Sources: Data provided by the Bangladesh authorities; and Fund staff estimates and projections. 
Table 8. Bangladesh: Banking Soundness Indicators, 1999-2006

(end-December)

\begin{tabular}{|c|c|c|c|c|c|c|c|c|}
\hline & 1999 & 2000 & 2001 & 2002 & 2003 & 2004 & 2005 & 2006 \\
\hline \multicolumn{9}{|l|}{ Capital adequacy } \\
\hline Regulatory capital as percent of risk-weighted assets & $\ldots$ & $\ldots$ & 1.0 & -0.6 & 1.1 & 0.1 & 1.8 & 2.3 \\
\hline Nationalized commercial banks & $\ldots$ & $\ldots$ & -7.0 & -7.5 & -14.9 & -13.7 & -10.4 & -9.6 \\
\hline Specialized development banks & $\ldots$ & $\ldots$ & -6.5 & -6.8 & -6.0 & -6.9 & -10.0 & -10.9 \\
\hline Private commercial banks & $\ldots$ & $\ldots$ & 7.5 & 7.3 & 13.1 & 9.4 & 8.7 & 8.1 \\
\hline Foreign commercial banks & $\ldots$ & $\ldots$ & 16.8 & 22.2 & 40.2 & 24.7 & 26.1 & 22.7 \\
\hline Regulatory tier 1 capital to risk-weighted assets & $\ldots$ & $\ldots$ & 4.7 & 4.4 & -3.5 & -1.1 & 0.6 & 0.0 \\
\hline Nationalized commercial banks & $\ldots$ & $\ldots$ & 3.6 & 2.6 & -4.6 & -2.2 & -0.1 & -0.5 \\
\hline Specialized development banks & $\ldots$ & $\ldots$ & -0.9 & -1.1 & -15.7 & -14.6 & -11.1 & -11.3 \\
\hline Private commercial banks & $\ldots$ & $\ldots$ & 4.3 & 5.1 & -9.3 & -8.0 & -11.2 & -12.5 \\
\hline Foreign commercial banks & $\ldots$ & $\ldots$ & 9.9 & 8.6 & 6.7 & 7.9 & 7.2 & 5.6 \\
\hline \multicolumn{9}{|c|}{ Sectoral composition of bank credit as percent of total loan exposure } \\
\hline Agriculture & $\ldots$ & 14 & 13 & 11 & 11 & 8 & 7 & $\ldots$ \\
\hline Industry & $\ldots$ & 33 & 31 & 23 & 20 & $\ldots$ & $\ldots$ & $\ldots$ \\
\hline Working capital finance & $\ldots$ & 9 & 9 & 22 & 19 & 24 & 23 & $\ldots$ \\
\hline Construction & $\ldots$ & 6 & 6 & 8 & 7 & $\ldots$ & $\ldots$ & $\ldots$ \\
\hline Wholesale and retail trade & $\ldots$ & 28 & 29 & 28 & 32 & $\ldots$ & $\ldots$ & $\ldots$ \\
\hline Banks & $\ldots$ & $\ldots$ & $\ldots$ & $\ldots$ & $\ldots$ & $\ldots$ & $\ldots$ & $\ldots$ \\
\hline Other & $\ldots$ & 10 & 12 & 8 & 12 & 68 & 70 & $\ldots$ \\
\hline Of which: share of housing finance & $\ldots$ & $\ldots$ & $\ldots$ & $\ldots$ & $\ldots$ & $\ldots$ & 4 & $\ldots$ \\
\hline \multicolumn{9}{|l|}{ Asset quality } \\
\hline Non-performing loans as percent of gross loans & 35.6 & $\ldots$ & 31.5 & 28.1 & 28.6 & 17.6 & 13.5 & 13.1 \\
\hline Nationalized commercial banks & $\ldots$ & $\ldots$ & 37.0 & 33.7 & 35.0 & 25.3 & 21.4 & 22.9 \\
\hline Specialized development banks & $\ldots$ & $\ldots$ & 61.8 & 56.2 & 55.6 & 42.9 & 34.8 & 33.7 \\
\hline Private commercial banks & $\ldots$ & $\ldots$ & 17.0 & 16.6 & 17.4 & 8.5 & 5.6 & 5.5 \\
\hline Foreign commercial banks & $\ldots$ & $\ldots$ & 3.3 & 2.6 & 2.0 & 1.5 & 1.3 & 0.8 \\
\hline Provisions as percent of NPLs & $\ldots$ & $\ldots$ & 25.4 & 25.3 & 24.9 & 19.1 & 24.3 & 26.3 \\
\hline Nationalized commercial banks & $\ldots$ & $\ldots$ & 16.9 & 15.6 & 14.8 & 3.4 & 13.2 & 15.8 \\
\hline Specialized development banks & $\ldots$ & $\ldots$ & 27.0 & 28.1 & 28.5 & 27.8 & 24.2 & 21.9 \\
\hline Private commercial banks & $\ldots$ & $\ldots$ & 42.9 & 41.6 & 40.8 & 44.1 & 50.2 & 51.7 \\
\hline Foreign commercial banks & $\ldots$ & $\ldots$ & 110.6 & 114.6 & 129.6 & 144.4 & 215.0 & 363.1 \\
\hline Number of banks with NPL > 10 percent of loans & $\ldots$ & $\ldots$ & $\ldots$ & 22 & 21 & 20 & 14 & 12 \\
\hline Nationalized commercial banks & $\ldots$ & $\ldots$ & $\ldots$ & 4 & 4 & 4 & 4 & 4 \\
\hline Specialized development banks & $\ldots$ & $\ldots$ & $\ldots$ & 4 & 4 & 4 & 4 & 4 \\
\hline Private commercial banks & $\ldots$ & $\ldots$ & $\ldots$ & 11 & 11 & 11 & 6 & 4 \\
\hline Foreign commercial banks & $\ldots$ & $\ldots$ & $\ldots$ & 3 & 2 & 1 & 0 & 0 \\
\hline \multicolumn{9}{|l|}{ Earnings and profitability } \\
\hline Gross profits as percent of (average) assets RoA & $\ldots$ & $\ldots$ & $\ldots$ & -0.2 & $\ldots$ & $\ldots$ & 2.2 & 1.3 \\
\hline Nationalized commercial banks & $\ldots$ & $\ldots$ & $\ldots$ & -0.2 & $\ldots$ & $\ldots$ & 2.1 & 0.5 \\
\hline Specialized development banks & $\ldots$ & $\ldots$ & $\ldots$ & 0.5 & $\ldots$ & $\ldots$ & -3.4 & -3.3 \\
\hline Private commercial banks & $\ldots$ & $\ldots$ & $\ldots$ & 1.7 & $\ldots$ & $\ldots$ & 2.5 & 1.8 \\
\hline Foreign commercial banks & $\ldots$ & $\ldots$ & $\ldots$ & 3.3 & $\ldots$ & $\ldots$ & 3.9 & 4.1 \\
\hline Gross income as percent of average assets & $\ldots$ & $\ldots$ & $\ldots$ & 8.8 & $\ldots$ & $\ldots$ & 15.2 & 9.2 \\
\hline Nationalized commercial banks & $\ldots$ & $\ldots$ & $\ldots$ & 7.4 & $\ldots$ & $\ldots$ & 10.7 & 5.0 \\
\hline Specialized development banks & $\ldots$ & $\ldots$ & $\ldots$ & 9.9 & $\ldots$ & $\ldots$ & 5.7 & 2.6 \\
\hline Private commercial banks & $\ldots$ & $\ldots$ & $\ldots$ & 9.8 & $\ldots$ & $\ldots$ & 22.6 & 14.0 \\
\hline Foreign commercial banks & $\ldots$ & $\ldots$ & $\ldots$ & 10.9 & $\ldots$ & $\ldots$ & 18.3 & 18.5 \\
\hline Personnel expenses as percent of noninterest expenses & $\ldots$ & $\ldots$ & $\ldots$ & $\ldots$ & $\ldots$ & $\ldots$ & 58 & 61 \\
\hline Nationalized commercial banks & $\ldots$ & $\ldots$ & $\ldots$ & $\ldots$ & $\ldots$ & $\ldots$ & 61 & 77 \\
\hline Specialized development banks & $\ldots$ & $\ldots$ & $\ldots$ & $\ldots$ & $\ldots$ & $\ldots$ & 68 & 77 \\
\hline Private commercial banks & $\ldots$ & $\ldots$ & $\ldots$ & $\ldots$ & $\ldots$ & $\ldots$ & 55 & 54 \\
\hline Foreign commercial banks & $\ldots$ & $\ldots$ & $\ldots$ & $\ldots$ & $\ldots$ & $\ldots$ & 53 & 44 \\
\hline Spread between reference loan and deposit rate & 6.7 & 6.7 & 6.7 & 6.6 & 6.1 & 5.3 & 5.4 & 5.7 \\
\hline Nationalized commercial banks & 6.0 & 6.0 & 6.0 & 6.2 & 5.8 & 4.9 & 5.4 & 5.2 \\
\hline Specialized development banks & 0.0 & 4.9 & 5.0 & 5.6 & 4.8 & 3.7 & 3.7 & 3.3 \\
\hline Private commercial banks & 8.4 & 8.0 & 7.6 & 7.1 & 6.6 & 5.5 & 5.1 & 6.0 \\
\hline Foreign commercial banks & 7.6 & 7.6 & 8.2 & 7.4 & 7.3 & 7.5 & 7.9 & 7.4 \\
\hline \multicolumn{9}{|l|}{ Liquidity } \\
\hline Liquid assets as percent of total assets & $\ldots$ & $\ldots$ & $\ldots$ & $\ldots$ & $\ldots$ & $\ldots$ & 8 & $\ldots$ \\
\hline Nationalized commercial banks & $\ldots$ & $\ldots$ & 32 & $\ldots$ & $\ldots$ & $\ldots$ & 3 & $\ldots$ \\
\hline Specialized development banks & $\ldots$ & $\ldots$ & 12 & $\ldots$ & $\ldots$ & $\ldots$ & 15 & $\ldots$ \\
\hline Private commercial banks & $\ldots$ & $\ldots$ & 33 & $\ldots$ & $\ldots$ & $\ldots$ & 10 & $\ldots$ \\
\hline Foreign commercial banks & $\ldots$ & $\ldots$ & 31 & $\ldots$ & $\ldots$ & $\ldots$ & 11 & $\ldots$ \\
\hline Net loans as percent of deposits & $\ldots$ & $\ldots$ & 84 & 83 & 76 & 81 & 71 & 75 \\
\hline Nationalized commercial banks & $\ldots$ & $\ldots$ & 70 & 70 & 68 & 69 & 59 & 63 \\
\hline Specialized development banks & $\ldots$ & $\ldots$ & 219 & 184 & 154 & 130 & 98 & 99 \\
\hline Private commercial banks & $\ldots$ & $\ldots$ & 89 & 87 & 74 & 85 & 78 & 82 \\
\hline Foreign commercial banks & $\ldots$ & $\ldots$ & 66 & 73 & 68 & 83 & 69 & 71 \\
\hline
\end{tabular}

Sources: Data provided by the Bangladesh authorities; and Fund staff estimates and projections.

\section{CInternational Monetary Fund. Not for Redistribution}


Table 9. Bangladesh: Structural Performance Criteria and Benchmarks for the Sixth Review Under the PRGF Arrangement

1. Separating the government's short-term cash liquidity needs from its debt-financing obligations by eliminating Bangladesh Bank's ad hoc Treasury System and introducing an auction mechanism that is

market-related with the amount of auctions preannounced (in line with MFD technical assistance recommendations).

2. Review and strengthen social programs designed to mitigate the impact on vulnerable groups of fuel price adjustments in line with the pricing formula introduced under the World Bank DSC.

3. Improving coordination between the VAT and income tax LTUs by:
(i) implementing unified selection criteria;
(ii) conducting joint audits for at least one-third of eligible audits conducted during June 2006-February 2007; and
(iii) assigning a unique taxpayer identification number for the LTUs. 1/ $2 /$

\section{March 31, 2007 \\ March 31, 2007 \\ March 31, 2007}

December 31, 2006

March 31, 2007
Not observed Not observed

Not observed

Observed

4. Eliminate the deficiency in the net open foreign exchange positions of the nationalized commercial banks in line with Bangladesh Bank's regulations.

5. Cabinet approval of the corporatization of Agrani Bank, Janata Bank, and Sonali Bank. 1/

$1 /$ Indicates structural performance criterion.

2/ Subsection (iii) only will be assessed as a structural performance criterion. Subsections (i) and (ii) will be assessed as structural benchmarks. 
Table 10. Bangladesh: Millennium Development Goals, 1990-2005 1/

\begin{tabular}{|c|c|c|c|c|c|c|}
\hline & 1990 & 1995 & 1998 & 2001 & 2004-05 & 2015 \\
\hline Eradicate extreme poverty and hunger & \multicolumn{6}{|c|}{ ( 2015 target=halve $1990 \$ 1$ a day poverty and malnutrition rates) } \\
\hline Poverty headcount ratio & 58.8 & $\ldots$ & $\ldots$ & 49.8 & 40.8 & 29 \\
\hline Population below US\$1 a day (percent) 2/ & 35.9 & 28.6 & 26.7 & 36.0 & $\ldots$ & 18 \\
\hline Poverty gap at US\$1 a day (percent) $2 /$ & 8.8 & 6.0 & 5.1 & 8.1 & $\ldots$ & $\ldots$ \\
\hline Share of income or consumption held by poorest 20 percent (percent) & $\ldots$ & $\ldots$ & $\ldots$ & 9.0 & $\ldots$ & $\ldots$ \\
\hline Prevalence of child malnutrition (percent of children under 5 ) & 65.8 & 57.0 & 62.0 & 52.0 & 48.0 & 26 \\
\hline Population below minimum level of dietary energy consumption (percent) & 35.0 & 40.0 & 38.0 & 30.0 & $\cdots$ & 18 \\
\hline Achieve universal primary education & \multicolumn{6}{|c|}{$(2015$ target $=$ net enrollment to 100$)$} \\
\hline Gross primary enrollment ratio (percent of relevant age group) & 72.0 & $\ldots$ & $\ldots$ & 86.7 & 97.0 & 100 \\
\hline Female primary enrollment ratio (percent of relevant age group) & 66.0 & $\ldots$ & $\ldots$ & 97.0 & 98.0 & 100 \\
\hline Percentage of cohort reaching grade 5 (percent) & $\ldots$ & $\ldots$ & 54.7 & 65.5 & 65.3 & $\ldots$ \\
\hline Youth literacy rate (percent of ages 15-24) & 42.0 & 44.5 & 46.5 & 48.4 & 49.7 & $\ldots$ \\
\hline Promote gender equality & \multicolumn{6}{|c|}{ ( 2015 target $=$ education rate to 100$)$} \\
\hline Ratio of girls to boys in primary and secondary education (percent) & 77.1 & 76.1 & 96.3 & 104.3 & 105.5 & 100 \\
\hline Ratio of young literate females to males (percent of ages 15-24) & 65.5 & 67.3 & 68.7 & 70.0 & 71.1 & 100 \\
\hline Share of women employed in the nonagricultural sector (percent) & 17.6 & 20.5 & 22.2 & 22.9 & 24.2 & $\ldots$ \\
\hline Proportion of seats held by women in national parliament (percent) & 10.0 & $\cdots$ & 9.0 & 9.0 & 2.0 & $\cdots$ \\
\hline Reduce child mortality & \multicolumn{6}{|c|}{ ( 2015 target $=$ reduce 1990 under 5 mortality by two-thirds) } \\
\hline Under 5 mortality rate (per 1,000 ) & 149 & 120 & $\ldots$ & 92 & 77 & 48 \\
\hline Infant mortality rate (per 1,000 live births) & 94 & 83 & $\ldots$ & 66 & 56 & 31 \\
\hline Immunization, measles (percent of children under 12 months) & 65 & 79 & 72 & 76 & 77 & $\cdots$ \\
\hline Improve maternal health & \multicolumn{6}{|c|}{ ( 2015 target $=$ reduce 1990 maternal mortality by three-fourths $)$} \\
\hline Maternal mortality ratio (modeled estimate, per 100,000 live births) & 500 & $\ldots$ & $\ldots$ & 380 & 300 & 100 \\
\hline Births attended by skilled health staff (percent of total) & $\cdots$ & 9.5 & 8.0 & 12.1 & 13.0 & $\cdots$ \\
\hline Combat HIVIAIDS, malaria, and other diseases & \multicolumn{6}{|c|}{ ( 2015 target $=$ halt and begin to reverse AIDS, etc.) } \\
\hline Prevalence of HIV, female (percent of ages 15-24) & $\ldots$ & $\ldots$ & $\ldots$ & $\ldots$ & $\ldots$ & $\ldots$ \\
\hline Contraceptive prevalence rate (percent of women ages 15-49) & 31 & 44.9 & 54 & $\cdots$ & 59 & $\cdots$ \\
\hline Number of children orphaned by HIVIAIDS & $\ldots$ & $\cdots$ & $\ldots$ & $\ldots$ & $\ldots$ & $\ldots$ \\
\hline Incidence of tuberculosis (per 100,000 people) & 263.8 & 246.0 & 246.0 & 245.9 & 229.3 & $\cdots$ \\
\hline Tuberculosis cases detected under DOTS (percent) & $\cdots$ & 6.7 & 19.3 & 25.9 & 43.5 & $\cdots$ \\
\hline Ensure environmental sustainability & \multicolumn{6}{|c|}{$(2015$ target $=$ various $3 /)$} \\
\hline Forest area (percent of total land area) & 7.0 & $\ldots$ & $\ldots$ & 7.0 & 7.0 & $\cdots$ \\
\hline Nationally protected areas (percent of total land area) & $\ldots$ & $\ldots$ & 0.8 & 0.8 & 0.8 & $\ldots$ \\
\hline GDP per unit of energy use (PPP \$ per kg oil equivalent) & 10.1 & 10.3 & 10.4 & 10.9 & 10.5 & $\ldots$ \\
\hline CO2 emissions (metric tons per capita) & 0.1 & 0.2 & 0.2 & 0.3 & $\ldots$ & $\ldots$ \\
\hline Access to an improved water source (percent of population) & 71.0 & $\ldots$ & $\cdots$ & 75.0 & $\ldots$ & $\cdots$ \\
\hline Access to improved sanitation (percent of population) & 23.0 & 41.0 & $\cdots$ & 48.0 & 48.0 & $\cdots$ \\
\hline Develop a global partnership for development & \multicolumn{6}{|c|}{$(2015$ target $=$ various $4 /)$} \\
\hline Youth unemployment rate (percent of total labor force ages 15-24) & 2.5 & 7.0 & 7.0 & 10.7 & $\ldots$ & $\cdots$ \\
\hline Fixed line and mobile telephones (per 1,000 people) & 2.1 & 2.5 & 3.9 & 8.3 & 37.0 & $\ldots$ \\
\hline Personal computers (per 1,000 people) & $\cdots$ & $\cdots$ & 1.0 & 1.9 & 11.9 & $\cdots$ \\
\hline \multicolumn{7}{|l|}{ General indicators } \\
\hline Population (in millions) & 104.0 & 116.5 & 123.9 & 131.5 & 139.2 & $\ldots$ \\
\hline Gross national income (in billions of U.S. dollars) & 31.0 & 39.2 & 45.1 & 49.6 & 61.3 & $\ldots$ \\
\hline GNI per capita (in U.S. dollars) & 300.0 & 340.0 & 360.0 & 380.0 & 440.0 & $\ldots$ \\
\hline Secondary enrollment ratio (percent of relevant age group) & 19.0 & $\ldots$ & $\ldots$ & 52.8 & 44.0 & 95 \\
\hline Adult literacy rate (percent of people ages 15 and over) & 34.2 & 36.5 & 38.3 & 50.4 & 41.1 & 90 \\
\hline Total fertility rate (births per woman) & 4.3 & 3.8 & 3.5 & 3.0 & 3.0 & $\ldots$ \\
\hline Life expectancy at birth (years) & 54.8 & 58.5 & 59.9 & 62.6 & 63.5 & 73 \\
\hline Aid per capita (current US\$) & 20.1 & 11.1 & 9.3 & 7.8 & 10.1 & $\ldots$ \\
\hline Investment (percent of GDP) & 17.1 & 19.1 & 21.6 & 23.1 & 24.0 & $\ldots$ \\
\hline
\end{tabular}

Sources: Bangladesh Economic Survey 2006, Household Income and Expenditure Survey 2000 and 2005, World Bank database; and

Fund staff estimates.

$1 /$ In some cases the data are for earlier or later years than those stated.

2/ Based on the 1995-96 Household Expenditure Survey and the 2000 and 2005 Household Income and Expenditure Survey; data may not be comparable across time periods due to methodological differences in survey design.

3 / Integrate the principles of sustainable development into country policies and programs and reverse the loss of environment resources. Halve the proportion of people without sustainable access to safe drinking water by 2015.

4/ Develop further an open, rule-based, predictable, nondiscriminatory trading and financial system. Address the special needs of land-locked countries and small island developing states. 


\section{INTERNATIONAL MONETARY FUND \\ BANGLADESH}

Staff Report for the 2007 Article IV Consultation-Informational Annex

Prepared by Staff Representatives for the 2007 Consultation with Bangladesh

(In consultation with Other Departments)

May 31, 2007

Contents

Page

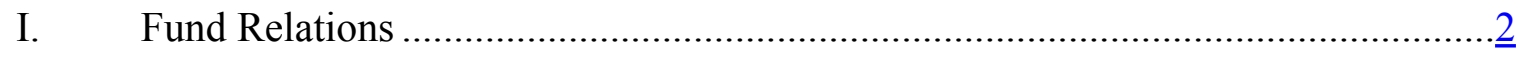

II. Relations with the World Bank...........................................................................

III. Relations with the Asian Development Bank ........................................................

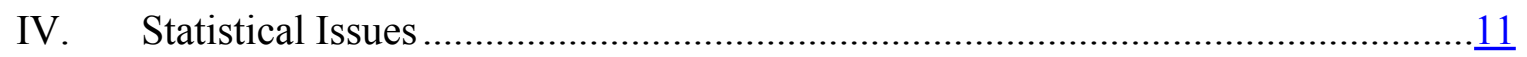




\section{APPENDIX I.}

\section{BANGLADESH-FUND RELATIONS}

(As of April 30, 2007)

I. Membership Status: Joined August 17, 1972; accepted the obligations under Article VIII, Sections 2, 3, and 4 on April 11, 1994.

II. General Resources Account:

Quota

Fund holding of currency

Reserve position in Fund

III. SDR Department:

Net cumulative allocation

Holdings $\underline{\text { SDR million }}$

533.30

533.08

0.25

$\underline{\text { SDR million }}$

47.12

0.88

$\underline{\text { SDR million }}$ 316.73

$$
\begin{array}{r}
\text { Percent Quota } \\
100.00 \\
99.96 \\
0.04
\end{array}
$$

Percent Allocation

100.00

1.88

IV. Outstanding Purchases and Loans: PRGF arrangements

Percent Quota

59.39

\section{Financial Arrangements:}

\begin{tabular}{lrrrr}
\hline Type & $\begin{array}{r}\text { Approval } \\
\text { Date }\end{array}$ & $\begin{array}{r}\text { Expiration } \\
\text { Date }\end{array}$ & $\begin{array}{r}\text { Amount approved } \\
\text { (SDR million) }\end{array}$ & $\begin{array}{r}\text { Amount drawn } \\
\text { (SDR million) }\end{array}$ \\
\hline PRGF & $6 / 20 / 03$ & $6 / 19 / 07$ & 400.33 & 316.73 \\
ESAF & $8 / 10 / 90$ & $9 / 13 / 93$ & 345.00 & 330.00 \\
SAF & $2 / 06 / 87$ & $2 / 05 / 90$ & 201.25 & 201.25
\end{tabular}

VI. Projected Payments to Fund (SDR million; based on existing use of resources and present holdings of SDRs):

\begin{tabular}{lrrrrr}
\hline & 2007 & 2008 & 2009 & 2010 & 2011 \\
\hline Principal & 0.00 & 4.95 & 14.85 & 29.70 & 49.88 \\
Charges/interest & 3.06 & 3.56 & 3.51 & 3.38 & 3.17 \\
$\quad$ Total & 3.06 & 8.51 & 18.36 & 33.08 & 53.05 \\
\hline
\end{tabular}




\section{Safeguards Assessment}

Under the Fund's safeguards assessment policy, the Bangladesh Bank (BB) is subject to a safeguards assessment with respect to an augmentation of access under the PRGF Arrangement approved on July 28, 2004. The assessment was completed on January 24, 2005 and concluded that safeguards in place at the BB require further improvement. Weaknesses were identified in the legal, financial reporting, internal audit and internal control areas, and the safeguards assessment recommended measures to address them.

\section{Exchange Arrangement}

Exchange regime. The exchange regime is characterized as a managed float with no preannounced path for the exchange rate. Until end-May 2003, the taka was fixed to the U.S. dollar, but was periodically adjusted. It was devalued on three occasions during 2000-02, when the trading band for BB's transactions was correspondingly widened or raised. From January 2002 until end-May 2003, the official band for the taka remained unchanged at Tk 57.4-58.4 per U.S. dollar. Authorized dealer (AD) banks set their own buying and selling rates for the U.S. dollar and other currencies generally within the band until October 2002. From November 2002, however, AD banks have set rates outside the band. Effective end-May 2003, BB no longer announced a trading band for its foreign exchange transactions.

At the last Article IV consultation (June 2005), the Executive Board did not approve the maintenance of the restriction on the convertibility and transferability of proceeds of current international transactions in nonresident taka accounts, but noted the authorities' intent to remove this restriction by end-June 2006 .

\section{Article IV Consultation}

The previous Article IV consultation was concluded on June 7, 2005 (IMF Country Report No. 05/241).

\section{Technical Assistance During 2005-07}

\section{5}

February and March: STA: data ROSC

February and September: MFD: bank restructuring

February and November: MFD: bank restructuring

March and August: $\quad$ MFD: central bank risk-based internal auditing standards 
March and October: MFD: bond market development.

May:

MFD: foreign exchange operations.

2006

February and March: $\quad$ FAD: tax administration

February and May: $\quad$ MFD: bank restructuring

February and August: MFD: bond market development

July: $\quad$ LEG: setting up a Financial Intelligence Unit

August and November: MFD: central bank internal audit

2007

January:

FAD/LEG: tax policy mission to review income and VAT taxes

March:

MFD: bond market development

March:

MFD: central bank internal audit

March:

MFD: bank restructuring

\section{Resident Representative}

The resident representative office was established in 1972. The current Resident Representative, Mr. Jonathan Dunn, took up the post in August 2004. 
APPENDIX II.

BANGLADESH-RELATIONS WITH THE WORLD BANK GROUP ${ }^{1}$

(As of May 2007)

The World Bank has an expanding assistance program in Bangladesh including investment and policy-based lending, analytical and advisory services, and lending and non-lending technical assistance. The Bank also maintains policy dialogue on a broad range of macroeconomic and sector issues. This annex, however, focuses on Bank activities that are complementary to those of the Fund.

\section{World Bank-Bangladesh relations and policy dialogue}

The Poverty Reduction Strategy Paper (PRSP) and the IMF and World Bank Joint Staff Advisory Note were discussed by the World Bank's Board on January 26, 2006. The PRSP was completed in October 2005 after a long and broad-based participatory process, building on the interim PRSP prepared in 2003.

As part of its nonlending services, the Bank has completed key reports. Major reports such as the Public Expenditure Review and the Poverty Assessment-prepared jointly with the AsDB - provided inputs for the country's poverty reduction strategy outlined in the PRSP. A new Poverty Assessment and an Institutional and Public Expenditure Review are being prepared this fiscal year. More recently, the Bank completed a review of trade policies in South Asia, as well as several country-specific reports, including, inter alia: Observance of Standards and Codes (ROSC), Promoting the Rural Non-Farm Sector in Bangladesh, Attaining the Millennium Development Goals in Bangladesh, Economics and Governance of NGOs in Bangladesh, Assessment of Social Safety Nets, End of MFA Quotas: Key Issues and Strategic Options for Bangladesh Ready Made Garment Industry, and Bangladesh PRSP Forum Update.

Several key reports are underway in FY07, such as, a Strategy for Growth and Employment, which will help assess the longer-term growth challenges facing Bangladesh (completed); and inter alia: a second Investment Climate Assessment, a Rural Finance Study, and the Dhaka Urban Poverty Study.

Restructuring state-owned enterprises (SOEs). The Bank has engaged in an extensive dialogue with the authorities on SOE-related issues. A report entitled Bangladesh: Review of Public Enterprise Performance and Strategy was discussed widely. In response to a request from the authorities, the Bank provided technical assistance to the Privatization Commission and assisted it in the preparation of the government's new Privatization Policy, which has since been endorsed by Cabinet. Dialogue relating to SOEs in the energy sector has been

\footnotetext{
${ }^{1}$ Prepared by World Bank staff.
} 
particularly intensive and the Bank has provided detailed recommendations to the authorities in areas relating to pricing policy and the regulatory regime for energy and other utilities. As part of a wide reform program of rolling back state ownership and control within the economy, the Enterprise Growth and Bank Modernization Project, approved in June 2004, is supporting restructuring of financial and nonfinancial SOEs. The Bank has also provided informal advice on improving performance of BIMAN, the national air carrier, and the government may hire the IFC as an advisor in this regard.

Restructuring the Financial System. The Bank has been actively engaging the authorities in a dialogue on financial sector reform. Together with the Fund, the Bank co-managed the Financial Sector Assessment Program report that was prepared in October 2002. With IDA financing, the government is implementing a program to strengthen the Central Bank. The mentioned Enterprise Growth and Bank Modernization Project has supported restructuring, corporatization, and eventual divestment of the nationalized commercial banks, of which Rupali Bank's divestment is nearing completion.

Trade Liberalization. In response to requests from the authorities, the Bank has provided regular analytical support to the government. The Bank-supported Export Diversification Project included a component designed to build capacity within the Tariff Commission for tariff analysis and WTO-related negotiations. In addition, the Bank has regularly provided trade-related policy notes as inputs into the annual budget preparation process. A report was also completed last year on trade policy regimes in South Asia and another trade study relating to Bangladesh and India is ongoing. The recently-completed Bangladesh Growth and Export Competitiveness Study examined key macro- and microeconomic factors affecting Bangladesh's competitiveness and provided specific recommendations on priority policy and institutional actions. Further, the Bank has completed a study on the ready-made garment sector, End of MFA quotas: Strategic Options for the Bangladesh Ready-Made Garment Industry. The study identifies several trade-related policy impediments.

Infrastructure Development. Infrastructure development is needed in the country for economic growth in general, and private sector development in particular. In this context, the Bank is helping to prepare a power sector strategy, and is supporting Power Sector Development technical assistance, which includes a project preparation facility, as well as projects in the areas of municipal services, urban infrastructure, water supply and telecommunications, and the recently signed railways project.

Strengthening Governance. The Bank has engaged the government in an active dialogue aimed at improving the investment climate by strengthening accountability and transparency. The new Country Assistance Strategy (CAS) has governance as its core, building several analytical reports on the subject. These include an Institutional and Governance Review, a Country Financial Accountability Assessment, a Country Procurement Assessment, and user surveys on the quality of service delivery. In addition, the Bank is providing technical assistance to the government for improving its procurement systems. 
The Bank is currently preparing a series of policy notes on selected aspects of public administration and governance, including policy advice to the Ministry of Finance, National Pay Commission, and the Ministry of Establishment in relation to civil service reform issues, including compensation policy.

As part of the Bank's regular public expenditure work, a set of policy notes were completed, and these will provide inputs to the ongoing Institutional and Public Expenditure Review. A programmatic approach is being taken to allow better cooperation with other donors. The unifying theme of the notes is the role of public expenditure on growth and poverty reduction, aiming to provide inputs for the government to use in their budget preparation process. As part of the Economic Management Technical Assistance Program, a TA project for the National Board of Revenue will assist in its capacity building, focusing on organizational restructuring, human resource management, development of ICT capacity, and strengthening customs, VAT and income tax administration, and training and research and statistics. The Bank was also instrumental in the establishment of the Anti-Corruption Commission (ACC) and continues to support its capacity development.

\section{The World Bank's Country Assistance Strategy}

A results-based Country Assistance Strategy (CAS), prepared jointly with AsDB, DfID, and JBIC, was discussed by the World Bank's Board on March 29, 2006. The CAS, covering the FY06-09 period, is aligned with Bangladesh's PRSP, with governance as the core focus across two main pillars: improving the investment climate and empowering the poor. The CAS aims to address sector governance issues in both pillars, as well as core governance issues. This mainstreaming of governance implies that all Bank Group interventions will be as much about governance as they will be about improving sector performance.

\section{The World Bank's Assistance Program}

The Bank has been assisting Bangladesh since FY1973. As of May 2007, the World Bank Group has approved 204 IDA credits, 4 IDA grants, and 1 IBRD loan for Bangladesh totaling US $\$ 12.1$ billion in original commitments. The active portfolio included 25 projects, representing US\$1.78 billion in net commitments and US\$1.3 billion in undisbursed funds. During FY05 and FY06, new commitments totaled US\$600 million and US\$461.5 million and disbursements totaled US\$695 million and US\$556 million, respectively (including budget support). The Bank is currently supporting projects in key sectors, including social and human development, rural development, energy and infrastructure, private sector development, finance, and environment.

In FY05, the Bank approved three IDA credits for a total of US\$600 million. These credits include two policy-based credits and an investment credit prepared within a SWAp framework. The development policy-based lending includes the second Development Support Credit (US\$200 million) and the Programmatic Education Sector Adjustment Credit (US\$100 million). DSC II continued to support the main themes of the I-PRSP-attaining 
macroeconomic stability, improving governance, enhancing human development, and ensuring social protection - and recognized the government's efforts at implementing broad reforms in pursuit of the I-PRSP goals. The investment credit was the Health, Nutrition and Population Sector Program II (US\$300 million), which contributes to a sector-wide program supported by several development partners.

In FY06, the Bank approved four credits for a total of US\$461.5 million. Of this amount, US\$300 million correspond to two policy-based credits: Third Development Support Credit (US\$200 million) and Second Programmatic Education Sector Adjustment Credit (US\$100 million). In addition, two investment credits were approved: Local Governance Support Project (US\$111.5 million) and Investment Promotion Finance Facility (US\$50 million).

So far in FY07, the Bank has approved a Railways Project (US\$40 million) and a Development Support Credit IV (\$200 million). It is also projected that the Bank will additionally commit US $\$ 175$ million in FY07. This amount would include about US $\$ 300$ million in budget support, and the rest would support projects in public procurement, social investment, microfinance, and health (Avian Flu).

As of May 2007, the IFC's held portfolio stood at US\$132.5 million. Of this, US\$102.9 million were under IFC's own account and US\$29.6 million for B-loan participants. Projects span a range of sectors including power, telecommunications, cement, and financial markets. No commitments were undertaken in FY05 or FY06. During FY04, IFC committed US\$5 million in a leasing company, ULC, US\$40 million to an oil and gas company, Cairn Energy, to support its expenditure needs in Bangladesh and India; a US\$30 million second investment in GrameenPhone; and as a small equity investment of US \$1.6 million in a local commercial bank, BRAC Bank, focusing on SMEs. In addition, in FY02, with the support of several donors, IFC started a regional SME technical assistance facility covering Bangladesh, Bhutan, Nepal, and north-east India.

\section{World Bank-Fund collaboration}

The Bank and the Fund have been working closely in Bangladesh, particularly in areas related to macroeconomic management, financial sector, reform of SOEs, tax policy and administration, public expenditure management, issues relating to financial accountability, and in setting up the Financial Intelligence Unit for anti-money laundering and combating terrorist financing purposes. Bank staff routinely participates in Article IV missions and provide feedback, as requested, on the macroeconomic framework and other aspects of the Fund's macroeconomic dialogue with the authorities. The Bank has also collaborated with the Fund in several areas related to the Report on Observance of Standards and Codes and safeguards assessment. Finally, Fund and Bank staff collaborated closely in preparing the Joint Staff Advisory Note of the PRSP, and in completing the complementary Development Support Credits and PRGF. 
APPENDIX III.

BANGLADESH-RELATIONS WITH THE ASIAN DEVELOPMENT BANK

(As of April 2007)

\section{Lending and technical assistance operations}

The Asian Development Bank (AsDB) has assisted Bangladesh since 1973. The cumulative commitment and disbursement to Bangladesh stood at $\$ 8.2$ billion and $\$ 5.8$ billion, respectively as of end-January 2007 . The cumulative outstanding loan as of end-January 2007 was $\$ 4.8$ billion. As of end-December 2006, public sector lending was dominated by four sectors: energy ( 25 percent), agriculture and natural resources (20 percent), transport and communications (20 percent), and education (10 percent). Lending in the other sectors, including finance, health, industry, water supply and sanitation, and multisector operations remain relatively small, although these sectors have been given more prominence in recent years. In addition, so far the AsDB has supported seven private sector projects, valued at $\$ 242$ million, including the Meghnaghat Power Project, which is the first build-own-operate power project, and GrameenPhone, which has substantially expanded access to mobile telecommunications in rural areas.

In 2006, AsDB operations focused on helping remove critical constraints on the investment climate and on empowering the poor by improving governance in the energy, transport, education, and integrated urban infrastructure sectors. Energy reforms aimed to help the government restructure the power sector to ensure adequate and reliable power supply at competitive prices through increased private sector participation and more effective management and operations. In the railways, the focus was on improving sector efficiency by restructuring Bangladesh Railway to make it a market-oriented business organization with better financial governance, human resources, and operational systems. Successful implementation of the Secondary Primary Education Development Program, which will improve the quality of primary education and its accessibility to children from poor households, is currently under way with AsDB as the lead agency, together with 10 other development partners.

AsDB approved four projects in 2006 totaling \$255.10 million for rural infrastructure improvement, secondary education, secondary towns water supply and sanitation, improvement of the capital market, and a multitranche financing facility for the railways sector (first subloan is $\$ 130$ million). AsDB also approved seven technical assistance grants totaling $\$ 5.71$ million.

\section{Country strategy and program}

AsDB's present Country Strategy and Program (CSP) for Bangladesh for 2006-10 was approved by the AsDB's Board on October 31, 2005. The new results-based CSP is part of a 
joint strategy prepared with the U.K.'s Department for International Development, Government of Japan, and World Bank. Over its first three years, the CSP proposes loans totaling about $\$ 1.8$ billion for 15 projects. This will be supported by a technical assistance grant program amounting to about $\$ 13.8$ million.

The CSP is aligned with the vision and priorities of the Bangladesh's national poverty reduction strategy, which aims to achieve the MDGs, including halving the number of poor people in the country by 2015 and delivering substantial improvement in almost all aspects of human development. The four partners' joint strategy is built on: (i) improving the investment climate for private sector-led growth and employment; (ii) advancing the social development agenda to empower the poor so that all benefit from growth; and (iii) addressing key governance issues to enable growth and social development.

Under the present country strategy and program, AsDB is playing a major role in energy, transport, education, and integrated urban development sectors, including urban health and urban water supply and sanitation. In other areas such as agriculture (i.e., agribusiness), water resources management, and the financial sector, AsDB is playing a supportive role to initiatives led by other development partners. Disaster mitigation, regional cooperation, gender, and environment continue to be addressed as key crosscutting issues.

\section{Economic and sector work program}

The AsDB publishes its Asian Development Outlook and its update every year in which it assesses macroeconomic performance. Beginning in 2001, the AsDB has also prepared quarterly economic updates. A new bimonthly Economic Indicators Update has been launched. In support of AsDB's Country Strategy and Program exercise, several new thematic assessments and sector studies have been completed. These include: thematic assessments for poverty, growth and poverty reduction, private sector development, governance, environment, and gender, and sector studies for transport, information and communications technology, water resource development, agriculture and rural development, fisheries, regional cooperation, finance, industry and trade sectors, Dhaka-Chittagong economic corridor development, and public sector borrowing capacity study. At the request of the government, a new study has been completed on the economic impact assessment of the proposed TATA investment in Bangladesh. An analysis of the household income and expenditure survey of 2005 to estimate income poverty based on new data has been completed. Several new studies will be undertaken on trade, transport and sectoral issues. 


\section{APPENDIX IV.}

\section{BANGLADESH-STATISTICAL ISSUES}

Macroeconomic data are adequate for surveillance, despite major shortcomings in national accounts, government finance statistics and balance of payments. Bangladesh is a participant in the General Data Dissemination System (GDDS), and its metadata have been posted on the Fund's Dissemination Standards Bulletin Board since March 2001. A ROSC data module mission to Bangladesh was undertaken in March 2005. The report is available on the IMF website and contains the following recommendations that cut across sectors:

- $\quad$ Legislation should be enacted to define the role of the Bangladesh Bureau of Statistics (BBS) and to provide it with sufficient powers to fulfill its mandate.

- Inter-agency cooperation should be improved, particularly for generating data on bank financing of the government and debt.

- $\quad$ Advance calendars for the release of data should be established, disseminated, and observed.

- $\quad$ The BBS should increasingly use its website to disseminate data and metadata in addition to paper publication. This would also ensure simultaneous data release to all users.

\section{National accounts}

The weakness of source data remains the primary deficiency. The BBS does not conduct an annual national accounts survey of business enterprises and source data are primarily from benchmark surveys, a census of manufacturing establishments conducted every two years, and biannual household expenditure surveys. Many of the benchmark surveys were conducted over five years ago and are based on outdated sample frames. The 2005 ROSC mission recommended that the BBS establish and maintain a business register for all economic units as a basis for surveys, which should be conducted annually.

The deficiencies in the data also affect compilation practices. There is heavy reliance on the use of fixed input-output ratios in estimating current value added. Thus estimates do not always reflect the rapid change in the structure of some industries. In addition, the use of inappropriate deflators and deflation techniques may undermine the reliability of the constant price estimates for some industries. A system of price indices for estimating national accounts at constant prices needs to be developed.

Bangladesh lacks quarterly estimates of GDP, but the compilation of quarterly national accounts, with technical assistance from the AsDB, is included in the authorities' GDDS plans for improvement. However, given resource constraints, improving the sources and 
methodology for annual data should be a short-term priority. Improvement in data sources should pave the way for the compilation of advance indicators of economic activity.

\section{Prices, wages, and employment}

Price statistics include a consumer price index (CPI), a producer price index (PPI), a wholesale price index (WPI), and unit value indices for external trade. The CPI and WPI are published with lags of two and three months, respectively, while unit value indices of exports and imports are available on an annual basis. The CPI and PPI weights are outdated, and the 2005 ROSC mission reiterated that the CPI should be compiled using weights derived from a household and expenditure survey completed in 2002.

Data for wages are prepared monthly, but employment and unemployment data are only available at irregular intervals.

\section{Government finance and debt}

The government finance statistics (GFS) continue to be affected by major shortcomings. There are large (but recently reduced) suspense accounts that are not always cleared at the end of the fiscal year, which impedes the classification of data by economic use and function. Foreign financed development expenditure is substantially understated due to reporting weaknesses. Three nonfinancial public enterprises - the railway, the postal office, and telephone and telegraph office - are included in central government budgetary accounts. Some subsidy items are classified as net lending.

Until recently, the Ministry of Finance had made no systematic attempt to compile comprehensive debt statistics, but instead relied on a variety of sources for these records. A Debt Management Wing was established within the Finance Division for this purpose. The ROSC mission recommended that this unit also include comprehensive data on governmentguaranteed debt in its debt statistics. External debt stock data by creditor are available with a lag of about 8 to 12 months, and the authorities do not have an automated system for external debt projections.

Annual data on the government's external financing for the budget and foreign grants are available with a lag of nine months. Domestic financing data provided by the National Savings Directorate with a lag of six weeks, were found to have serious shortcomings. Efforts continue to improve the quality and timeliness of the external financing data, which remains weak.

Although annual GFS data through the fiscal year ending June 30, 2004 were provided by the authorities for inclusion in the Government Finance Statistics Yearbook, the coverage of the data was limited to budgetary central government, because no data are collected on local 
governments. No quarterly or monthly data are reported to the IFS. During the GFS mission in January/February 2004, the authorities adopted a proposed migration plan to implement the GFSM 2001.

\section{Monetary accounts}

Monthly accounts of the Bangladesh Bank (BB) and other depository corporations are available with a lag of six weeks. In addition, BB also produces a weekly publication (shared with the Fund) that is available with a lag of about five to six weeks. In line with earlier Fund recommendations, BB is reporting its monetary accounts to the Fund electronically. Several of the ROSC mission recommendations were put into practice, including recording on an accrual basis the interest earned on BB's special treasury bills and recording of overdrafts as loans rather than netting them out with deposits. BB has embarked on a project to adapt the monetary statistics with the methodology of the Monetary and Financial Statistics Manual and has reported test data using the standardized report forms (SRFs), introduced in October 2004. These data are being reviewed by STA and will be published in the IFS Supplement on Monetary and Financial Statistics when they are finalized. BB has also expressed a strong interest in establishing an integrated database that links monetary statistics to accounting records and yields alternative, transparent, and consistent presentations of monetary statistics for different users.

\section{Balance of payments}

Balance of payments data are broadly on the basis of the Fifth Edition of the Balance of Payments Manual (BPM5). Apart from export shipments data, most other statistics are recorded on a cash basis, with the banking and exchange control records as the primary source of data. The foreign direct investment data are derived from enterprise surveys. Summary balance of payments (BOP) data are compiled and disseminated on a monthly basis; quarterly statistics for all the major accounts are consistent with monthly data; and annual BOP data are presented with a detailed classification. Data sources for estimating goods for processing - a significant component of the $\mathrm{BOP}$ - are not adequate, and respective adjustments to goods imports and exports are not available. Nontrade activities of companies operating in the export processing zones are included; however, the financial transactions of offshore banks are not. Data on private sector external borrowing, the transactions of foreign direct investors, and workers' remittances through the informal hundi banking system are not fully incorporated in the official published data. Official foreign direct investments may not be fully reported. Data on income and transfers are incomplete. Data on suppliers' credit to the government are available on a monthly basis with a three-month lag, but are not comprehensive. 
Bangladesh: Table of Common Indicators Required for Surveillance

May 23, 2007

\begin{tabular}{|c|c|c|c|c|c|c|c|}
\hline & \multirow{2}{*}{$\begin{array}{c}\text { Date of } \\
\text { latest } \\
\text { observation }\end{array}$} & \multirow{2}{*}{$\begin{array}{c}\text { Date } \\
\text { received }\end{array}$} & \multirow{2}{*}{$\begin{array}{c}\text { Frequency } \\
\text { of } \\
\text { data }^{6}\end{array}$} & \multirow{2}{*}{$\begin{array}{l}\text { Frequency } \\
\text { of } \\
\text { reporting }\end{array}$} & \multirow{2}{*}{$\begin{array}{l}\text { Frequency } \\
\text { of } \\
\text { publication }^{6}\end{array}$} & \multicolumn{2}{|c|}{ Memo Items: } \\
\hline & & & & & & $\begin{array}{c}\text { Data Quality- } \\
\text { Methodological soundness }^{7}\end{array}$ & $\begin{array}{c}\text { Data Quality- } \\
\text { Accuracy and reliability }\end{array}$ \\
\hline Exchange Rates & $5 / 10 / 07$ & $5 / 10 / 07$ & $\mathrm{D}$ & $\mathrm{D}$ & $\mathrm{D}$ & & \\
\hline $\begin{array}{l}\text { International Reserve Assets and } \\
\text { Reserve Liabilities of the Monetary } \\
\text { Authorities }^{1}\end{array}$ & $5 / 10 / 07$ & $5 / 10 / 07$ & $\mathrm{D}$ & $\mathrm{D}$ & $\mathrm{D}$ & & \\
\hline Reserve/Base Money & $5 / 10 / 07$ & $5 / 10 / 07$ & $\mathrm{D}$ & $\mathrm{D}$ & M & O, O, LO, LO & O, LO, O, O, O \\
\hline Broad Money & Mar. 2007 & $5 / 9 / 07$ & M & M & M & & \\
\hline Central Bank Balance Sheet & Mar. 2007 & $5 / 9 / 07$ & W/M & W/M & M & & \\
\hline $\begin{array}{l}\text { Consolidated Balance Sheet of the } \\
\text { Banking System }\end{array}$ & Mar. 2007 & $5 / 9 / 07$ & M & M & M & & \\
\hline Interest Rates ${ }^{2}$ & $5 / 9 / 07$ & $5 / 9 / 07$ & W & W & $\mathrm{D}$ & & \\
\hline Consumer Price Index & Mar. 2007 & $3 / 07 / 07$ & M & M & M & & \\
\hline $\begin{array}{l}\text { Revenue, Expenditure, Balance and } \\
\text { Composition of Financing }^{3}-\text { General } \\
\text { Government }^{4}\end{array}$ & $\mathrm{n} / \mathrm{a}$ & $\mathrm{n} / \mathrm{a}$ & $\mathrm{n} / \mathrm{a}$ & $\mathrm{n} / \mathrm{a}$ & $\mathrm{n} / \mathrm{a}$ & O, LO, LNO, LO & $\mathrm{LO}, \mathrm{O}, \mathrm{O}, \mathrm{O}, \mathrm{O}$ \\
\hline $\begin{array}{l}\text { Revenue, Expenditure, Balance and } \\
\text { Composition of Financing }{ }^{3}-\text { Central } \\
\text { Government }\end{array}$ & Feb. 2007 & $4 / 15 / 07$ & $M / Q$ & Q & Q & & \\
\hline $\begin{array}{l}\text { Stocks of Central Government and } \\
\text { Central Government-Guaranteed Debt }{ }^{5}\end{array}$ & Mar. 2007 & $5 / 20 / 07$ & M & M & M & & \\
\hline External Current Account Balance & Feb. 2007 & $5 / 3 / 07$ & M & M & M & O, LO, O, LO & LO, LO, LO, O, O \\
\hline $\begin{array}{l}\text { Exports and Imports of Goods and } \\
\text { Services }\end{array}$ & Feb. 2007 & $5 / 3 / 07$ & M & M & M & & \\
\hline GDP/GNP & $2005 / 06$ & $5 / 22 / 07$ & $A$ & $A$ & $A$ & O, LNO, LO, LO & LNO, LO, LNO, LNO, O \\
\hline Gross External Debt & Jun. 2005 & $9 / 15 / 05$ & A & $\mathrm{A} / \mathrm{M}$ & $A$ & & \\
\hline
\end{tabular}

${ }^{1}$ Includes reserve assets pledged or otherwise encumbered as well as net derivative positions.

${ }^{2}$ Both market-based and officially determined, including discount rates, money market rates, rates on treasury bills, notes, and bonds.

${ }^{3}$ Foreign, domestic bank, and domestic nonbank financing.

${ }^{4}$ The general government consists of the central government (budgetary funds, extra budgetary funds, and social security funds) and state and local governments.

${ }^{5}$ Including currency and maturity composition

${ }^{6}$ Daily (D); Weekly (W); Monthly (M); Quarterly (Q); Annually (A); Irregular (I); Not Available (NA).

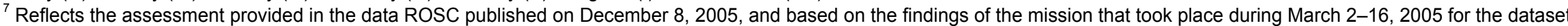

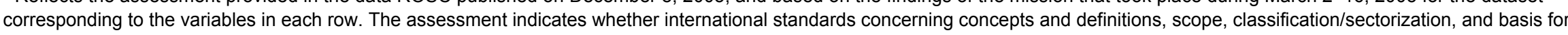
recording are fully observed (O), largely observed (LO), largely not observed (LNO), or not observed (NO).

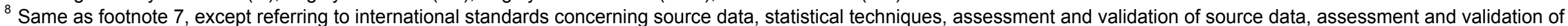
intermediate data and statistical outputs, and revision studies.

(CInternational Monetary Fund. Not for Redistribution 


\section{Statement by the IMF Staff Representative \\ June 22, 2007}

1. This statement provides information that has become available since the circulation of the staff report. It does not alter the thrust of the staff appraisal.

2. Inflation rose further but external indicators remain strong. Reflecting the impact of fuel price adjustments, April inflation rose to 8.3 percent (y/y), consistent with staff's FY07 average annual inflation projection of 7.2 percent. Broad money and credit growth moderated somewhat in April in line with staff projections. Buoyant exports and remittance flows were sustained in April and May, and gross official reserves reached $\$ 4.8$ billion as of mid-June, while the taka continues to hover around 69 per U.S. dollar.

3. A preliminary FY08 budget was presented on June 7. While the revenue target is fully consistent with staff's projection of 10.7 percent of GDP, current expenditures are higher by 0.4 percent of GDP and are expected to be financed by more foreign grants, based on updated donor commitments. The main base broadening measure is the extension of VAT to previously exempt services. The budget speech also announces plans to adjust various fees and charges in support of improved nontax revenue. On the expenditure side, higher pay and allowances reflect an upward correction in allowances and/or new recruitment in the defense, home affairs, and health ministries, while subsidies include a higher allocation for social safety net programs and for farmers to offset the impact of higher diesel prices. Following a two-week period of public comment, the budget is to be finalized and submitted for

\begin{tabular}{|lrr|}
\hline \multicolumn{2}{|c|}{$\begin{array}{c}\text { FY08 Budget } \\
\text { (In percent of GDP) }\end{array}$} & \\
& & \\
& & Prelim. \\
& Staff Proj. & Budget 1/ \\
\hline Total revenue & 10.7 & 10.7 \\
Total expenditure & 15.9 & 16.2 \\
Current expenditure & 8.9 & 9.3 \\
Of which: Pay and allowances & 2.3 & 2.5 \\
Of which: Subsidies and transfers & 2.8 & 3.1 \\
Capital spending and net lending & 7.0 & 6.9 \\
Overall balance (excluding grants) & -5.2 & -5.6 \\
Excluding BPC debt operation & -3.6 & -4.2 \\
Net financing & 5.2 & 5.6 \\
External & 1.5 & 2.0 \\
Domestic & 3.7 & 3.6 \\
Excluding BPC debt operation & 2.2 & 2.2 \\
\hline 1/ Preliminary budget posted for public comment on June 7, 2007 at www.mof.gov.bd. \\
\hline
\end{tabular}
cabinet approval in late June. In implementing the FY08 budget, the authorities will need to be prepared to adjust spending plans if the assumed higher foreign financing does not materialize so that domestic financing remains within budget limits.

4. Several trade taxes were modified in the budget. A 4 percent surcharge on imports (earmarked for infrastructure development) was consolidated into the tariff system, two supplementary duty rates were merged, and a number of goods were removed from the zero tariff band as part of a reform of the import tariff regime that aims to be revenue neutral. At the same time, an export withholding tax of 0.25 percent was introduced. These changes have reduced tariff dispersion by consolidating some charges and may help reduce evasion by 
removing many goods from the zero rate tariff band, but have had no significant impact on average levels of protection.

5. The FY08 budget does not resolve the main issues emphasized in the staff report, particularly regarding the need for timely adjustment of administered prices and fundamental revenue reform. Timely price adjustment would restrain subsidies and transfers and avoid the need to assume nonperforming loans of loss-making SOEs in the future. The revenue policies announced with the budget should be sufficient to produce the modest improvement in revenue forecast for FY08, but the significant improvement in revenue necessary to meet development objectives over the medium term would require more comprehensive reform as outlined in the staff report. In this regard, the staff welcomes the authorities' disclosure in the budget speech that initiation of such comprehensive revenue system reform is under consideration.

6. Tax administration reforms also need to be accelerated. With the exception of a proposed introduction of a universal self assessment scheme to encourage voluntary tax compliance, the budget speech did not reveal additional tax administration reforms, such as the needed consolidation of the two large taxpayer units (LTUs) or separation of the tax policy and administration functions. However, the process of assigning a unique identification number for taxpayers in the LTUs (a structural performance criterion for endMarch under the PRGF-supported program) was completed at end-May.

\section{Further financial sector reforms are under way, but the sale of Rupali Bank is} still pending. Several measures were announced with the budget that will support further development of a secondary market for government debt instruments, including the elimination of the upfront tax on government bond sales and plans to increase the use of yield-based auctions and longer-term bonds. Corporatization of the three NCBs was completed in early June and the government has advertised positions for new managers. Bangladesh Bank raised the banks' minimum capital adequacy ratio from 9 to 10 percent of risk-weighted assets as of end-2007, as part of steps to further strengthen prudential regulations. In recognition of positive steps taken to strengthen its surveillance institutions, Bangladesh was recently invited to join the Egmont Group of financial intelligence units that combat money laundering and terrorist financing. With respect to Rupali Bank, there are no signs of when the preferred bidder, who was announced at end-August 2006, might conclude the purchase. 


\section{INTERNATIONAL MONETARY FUND}

Public Information Notice

Public Information Notice (PIN) No. 07/75

FOR IMMEDIATE RELEASE

June 29, 2007
International Monetary Fund $70019^{\text {th }}$ Street, NW

Washington, D. C. 20431 USA

\section{IMF Executive Board Concludes 2007 Article IV Consultation with Bangladesh}

On June 22, 2007, the Executive Board of the International Monetary Fund (IMF) concluded the Article IV consultation with Bangladesh. ${ }^{1}$

\section{Background}

Bangladesh's growth outlook and external position remain robust, but inflation has picked up. The economy continued to grow at over $6 \frac{1}{2}$ percent in the fiscal year ending June 2006 (FY06) spurred by strong exports and investment. GDP growth is expected to continue at around $61 / 2$ percent in FY07 despite some supply-related disruptions, with lower agricultural growth offset by strong manufacturing and service activities. Inflation has recently picked up to over 7 percent reflecting increases in both food and nonfood prices.

The exchange rate has been relatively stable and international reserves have increased throughout the period of political upheaval. Reserves have reached beyond US $\$ 4$ billion (approaching three months of imports) on the back of continued strong remittances and exports, which are growing at 25 and 21 percent, respectively.

Overall macroeconomic stability has been maintained, but fiscal performance continues to suffer from structural weaknesses. Revenue performance has consistently been

\footnotetext{
${ }^{1}$ Under Article IV of the IMF's Articles of Agreement, the IMF holds bilateral discussions with members, usually every year. A staff team visits the country, collects economic and financial information, and discusses with officials the country's economic developments and policies. On return to headquarters, the staff prepares a report, which forms the basis for discussion by the Executive Board. At the conclusion of the discussion, the Managing Director, as Chairman of the Board, summarizes the views of Executive Directors, and this summary is transmitted to the country's authorities.
} 
below budget targets. In addition, spending accelerated early in FY07 causing a surge in domestic financing of the government while delays in external disbursements further aggravated the situation. This forced expenditure cuts later in the year to contain the overall deficit and domestic financing. As a result, development expenditure was significantly underexecuted.

The growth in monetary and credit aggregates increased considerably in FY07. Broad money growth reached a high of 22 percent in December and private credit growth has been close to 20 percent for much of the year. Reflecting better control of government finances since January 2007, the growth in monetary aggregates has declined somewhat, but still remains above targeted levels. With ample liquidity, bank lending and deposit interest rates have seen only modest increases.

Petroleum prices have not kept pace with international prices leading to a deterioration of finances of state-owned enterprises. After the April fuel price adjustments, domestic prices of diesel and kerosene are around 80 percent of their breakeven level and below prices in neighboring countries. The losses accumulated in the past have been financed through loans from the nationalized commercial banks, and about two-thirds of these loans are overdue contributing to the weak financial health of these banks.

The Bangladesh Bank has further advanced reforms aimed at deepening financial markets. The regulatory framework has been strengthened, off-site and on-site supervision has been enhanced and steps taken to restructure, corporatize, and privatize the large nationalized commercial banks. These reforms have contributed to reducing the share of the large nationalized banks and strengthening the banking system. However, interest rate spreads are high and point to inefficiencies in the domestic banking system that detract from efficient financial intermediation.

The current transitional government has moved to address several areas where reforms had stalled. These include adjustments in fuel and electricity prices, introduction of a Financial Intelligence Unit, reconstituting the Anti-Corruption Commission, and separating the judiciary from the executive branch.

\section{Executive Board Assessment}

Executive Directors welcomed that macroeconomic stability with strong growth has been maintained for several years, and that most of the objectives of the Poverty Reduction and Growth Facility-supported program were achieved. Inflation was largely contained, poverty has been reduced, and good progress has been made toward achieving the Millennium Development Goals. The shift to a flexible exchange rate strengthened the external sector, helping to support double-digit growth in exports and remittances and a significant improvement in international reserves. Although fiscal discipline was maintained, revenues fell short. Looking forward, growth is expected to remain healthy, underpinned by buoyant exports, strong remittance flows, and continued reform efforts. At the same time, weak revenue collections, poor infrastructure, low skill levels, and governance issues remain important impediments to sustained growth and further poverty reduction. 
Directors observed that revenue collections are insufficient to meet development needs or to support the desired reductions in tariffs and supplementary duties. They called for a fundamental reform of the tax system by broadening the tax base, separating the responsibility for tax policy and collection, simplifying VAT and income tax legislation, and consolidating and strengthening the institutional structure of tax administration. Directors welcomed the recent steps to consolidate import taxes, but observed that the rate of effective protection remains high.

Directors welcomed the planned reforms in the area of public financial management and the adoption by major ministries of the medium-term budget framework, but drew attention to the underexecution of development spending. They hoped that the adoption of a regulatory framework for the Public Procurement Act would raise the efficiency of project implementation.

Directors supported the authorities' efforts to stem state-owned enterprise losses and ease infrastructure bottlenecks. They welcomed the fuel price adjustments by the stateowned petroleum company, but called for more timely adjustments through an automatic pricing formula. Directors recommended adjusting the price of domestically produced natural gas to encourage efficient gas usage and raise government revenue.

Directors commended the authorities for their progress in strengthening central bank operations and improving the institutional framework for monetary policy, and the steps taken to develop a secondary market for government securities. They recommended further monetary tightening in the face of strong inflows and higher inflation, and with money and credit aggregates above targeted levels. The recent pickup in inflation could become entrenched in the absence of corrective policies.

Directors considered that the flexible exchange rate regime has helped maintain competitiveness, and remains appropriate. With reserves now at a more comfortable level, exchange market intervention should be confined to alleviating disorderly conditions, and thus allowing greater flexibility in the nominal rate to support stabilization objectives. Directors urged the authorities to remove the remaining exchange restriction on the transferability of funds in nonresident taka accounts.

Directors commended the authorities for improving financial sector surveillance, and recommended that they build on recent financial sector reforms. They welcomed the corporatization of the remaining state-owned banks, hoped for a successful privatization of Rupali Bank, and encouraged the authorities to prepare the other state banks for eventual divestment. Directors called on the authorities to bring banking sector prudential guidelines more in line with international standards and strengthen monitoring, particularly in the context of rapid credit growth. Directors commended the authorities for implementing many of the recommendations of the 2003 Financial Sector Assessment Program (FSAP), and welcomed the authorities' request for an FSAP update.

Directors supported the recent reforms to promote transparency, good governance in public administration, fair elections, and the prevention of money laundering and terrorist 
financing. These reforms, if sustained, will improve overall efficiency and boost the investment climate.

Directors noted that data are broadly adequate for surveillance purposes, but called for continued efforts to improve data quality, including banking soundness indicators, and national accounts, fiscal and debt statistics.

Directors looked forward to continued close cooperation and dialogue between the authorities and the staff in support of Bangladesh's reform objectives, possibly in the context of a Fund-supported program.

Public Information Notices (PINs) form part of the IMF's efforts to promote transparency of the IMF's views and analysis of economic developments and policies. With the consent of the country (or countries) concerned, PINs are issued after Executive Board discussions of Article IV consultations with member countries, of its surveillance of developments at the regional level, of post-program monitoring, and of ex post assessments of member countries with longer-term program engagements. PINs are also issued after Executive Board discussions of general policy matters, unless otherwise decided by the Executive Board in a particular case. 
Bangladesh: Key Economic Indicators, FY03-07 1/

FY03 FY04 FY05 FY06 FY07

Proj.

National income and prices (percent change)

Real GDP

GDP deflator

CPI inflation (annual average) 2/

$\begin{array}{lllll}5.3 & 6.3 & 6.0 & 6.6 & 6.7 \\ 4.5 & 4.2 & 5.1 & 5.2 & 6.3 \\ 4.4 & 5.8 & 6.5 & 7.2 & 7.2\end{array}$

Central government operations (percent of GDP)

Total revenue

Tax

Nontax

$\begin{array}{rrrrr}10.3 & 10.2 & 10.5 & 10.7 & 10.4 \\ 8.3 & 8.2 & 8.5 & 8.5 & 8.3 \\ 2.0 & 1.9 & 2.0 & 2.2 & 2.1 \\ & & & & \\ 13.7 & 13.3 & 13.8 & 13.9 & 14.0 \\ 8.1 & 7.8 & 8.4 & 8.4 & 9.0 \\ 1.9 & 1.6 & 1.7 & 1.8 & 1.9 \\ 2.3 & 2.4 & 2.8 & 2.6 & 3.0 \\ 5.4 & 5.0 & 5.0 & 4.7 & 4.3 \\ 0.1 & 0.5 & 0.4 & 0.8 & 0.7 \\ & & & & \\ -3.4 & -3.1 & -3.3 & -3.2 & -3.5 \\ -1.5 & -1.4 & -1.7 & -1.4 & -1.6 \\ 3.4 & 3.1 & 3.3 & 3.2 & 3.5 \\ 1.2 & 1.8 & 1.7 & 2.1 & 2.3 \\ 2.1 & 1.3 & 1.6 & 1.2 & 1.2 \\ & & & & \\ 51.1 & 51.0 & 50.1 & 49.3 & 46.9 \\ & & & & \\ 12.2 & 13.5 & 17.1 & 19.6 & 13.4 \\ 12.6 & 17.5 & 17.0 & 18.3 & 15.1 \\ 15.6 & 13.8 & 16.7 & 19.3 & 17.5\end{array}$

Overall balance (excluding grants) 4/

Primary balance 4/

Financing (net)

Domestic 4/ 5/

External

Total central government debt (percent of GDP)

Balance of payments (in billions of U.S. dollars) 6/

Exports, f.o.b.

(Annual percent change)

Imports, f.o.b.

(Annual percent change)

Current account

(Percent of GDP)

Gross official reserves (in billions of U.S. dollars)

In months of imports of goods and nonfactor services

$\begin{array}{lllll}6.5 & 7.5 & 8.6 & 10.4 & 12.5\end{array}$

$\begin{array}{rrrrr}9.5 & 15.9 & 14.0 & 21.6 & 19.9\end{array}$

$\begin{array}{llllll}-8.7 & -9.8 & -11.9 & -13.3 & -16.0\end{array}$

$\begin{array}{rrrrr}13.1 & 13.0 & 20.6 & 12.1 & 20.0\end{array}$

$\begin{array}{lllll}0.2 & 0.2 & -0.6 & 0.6 & 0.5\end{array}$

$\begin{array}{lllll}0.3 & 0.3 & -0.9 & 0.9 & 0.8\end{array}$

$\begin{array}{lllll}2.5 & 2.7 & 2.9 & 3.5 & 5.0\end{array}$

$\begin{array}{lllll}2.9 & 2.8 & 2.5 & 2.7 & 3.2\end{array}$

Memorandum item:

Nominal GDP (in billions of taka)

$3,006 \quad 3,330 \quad 3,707 \quad 4,157 \quad 4,715$

Sources: Data provided by the Bangladesh authorities; and Fund staff estimates and projections.

$1 /$ Fiscal year begins July 1.

2/ CPI uses FY96 weights.

3/ Consists of other capital, net lending, food account balances, check float and discrepancy.

4/ Includes assumption of BPC liabilities of 1.6 percent of GDP in FY08.

$5 /$ Includes estimated privatization receipts of 0.5 percent of GDP in FY07.

6 / Balance of payments is presented on the basis of BPM5. 


\section{Statement by Adarsh Kishore, Executive Director for Bangladesh and R. Bannerji, Senior Advisor to Executive Director \\ June 22, 2007}

\section{Introduction:}

1.1 The Bangladesh Authorities take this opportunity to place on record their thanks and appreciation to IMF staff for the Article IV Consultation and the Sixth PRGF Review mission conducted in April 2007. The Authorities are in broad agreement with the observations, recommendations and the policy advice on macro-economic and structural reforms covered in the Staff Report.

1.2 Since November 2006, the already vitiated political situation in Bangladesh began to worsen, and by January 2007, assumed dangerous proportions. The street riots, violent hartals and blockades brought economic and social life to a virtual standstill. To put an end to the destabilizing political situation, the President declared Emergency on January 11, 2007 and formed a new Caretaker Government (CTG), the major responsibility of which, inter alia, is to create a congenial environment to conduct a free and fair election expeditiously and in a transparent manner. The new CTG has come down heavily against corruption. A number of studies in recent years have determined that corruption in Bangladesh consumes 1-2 percent of GDP. In order to pursue cases against corrupt individuals, the Judiciary and Anti-Corruption Commission have been strengthened and more court houses are being set up to enable quick disposal of the growing number of cases.

1.3 In spite of the difficult political situation, Bangladesh economy has made remarkable progress buttressed by wide-ranging reforms supported by the World Bank Development Support Credit (DSC), Poverty Reduction Growth Facility (PRGF) of IMF and DFID-supported Financial Management Reform Programme. Strong growth and well-designed policies to attack poverty during the last decade seemed to have paid dividends as revealed in the recent Household Income and Expenditure Survey (HIES). The proportion of people living in poverty fell from 49 percent in 2000 to 40 percent, with the hardcore poverty falling from 34 percent to 25 percent. In FY 2005-06, economic growth posted a historic high rate of 6.7 percent, thanks to the robust growth of both agriculture and industry. Bangladesh continues to post current account surpluses reflecting strong growth of export and remittance inflows. Gross reserves, at over $\$ 4$ billion are comfortable.

1.4 The Government of Bangladesh remains fully committed to the earnest pursuit of reforms despite some difficult domestic and external circumstances. Some of the reform measures implemented in recent times include adjustment of oil prices, rationalization of electricity tariff, corporatization of national commercial banks, reconstitution of Election Commission, Anti-Corruption Commission. These reforms are the building blocks for faster growth to reduce poverty, and thereby improve the welfare of the people. Bangladesh's development and poverty reduction strategy is enshrined in the document named "Unlocking the Potential: National Strategy for Accelerated Poverty Reduction (NSAPR)". The budgets are formulated in consonance with the overarching framework of NSAPR, and their effective implementation is aided by Medium-term Budget Framework (MTBF), that has now been extended to14 important ministries that spend 60 percent of the total budget. 


\section{Budget Highlights}

2.1 The recently announced national budget has set out the major policy directions of the new CTG. The FY 2007-08 budget includes: emphasis on maintaining a favorable macro economic environment; rationalization of the trade regime; decisive steps to assume SOE liabilities, principally of Bangladesh Petroleum Corporation and Power Development Board; significantly higher allocation in strategic sectors of power and agriculture, including a provision for diesel subsidy to poor farmers facing higher irrigation cost. Safety net programmes have been deepened and widened and new programs added with more focused targeting. The Authorities have reconstituted the hitherto ineffective Anti-Corruption Commission and further demonstrated their commitment to elimination of corruption by signing UN Convention against Corruption. The judiciary has been separated from the executive organ. Human resource development constitutes 25 percent of the total budget allocation with education and health receiving 15.2 percent and 7 percent respectively. A Universal Self-Assessment Procedure of tax return has been introduced. The tariff structure has been simplified and the tariff distortion brought to a minimum. The trade regime has been further liberalized. Both the VAT net and Income-tax net have been widened.

Government borrowings from ad hoc treasury bills have been replaced by transparent auction based system.

2.2 In the absence of a working parliament in the country, the Government has ensured an extensive consultative process involving former finance ministers, finance secretaries, intelligentsia, civil society, non-government organizations, journalists, and people at large both before and after the announcement of the budget. Following the declaration of the budget, the government allowed 10 days for receiving suggestions, ideas and comments from individuals, groups and institutions. All such inputs are currently being processed and the ones determined as having merit would be considered before final approval.

2.3 In the coming fiscal year, the Government has attached the highest importance to the implementation of the budget. To this end the Finance Ministry is mobilizing its manpower and resources for monitoring the implementation of budget. The Authorities put special allocation of resources to in major ministries that cover the key sectors to conduct special/performance audit, with the work to be outsourced to private sector audit firms of good standing. The Finance Division has introduced an Internal Control Manual to be uniformly applied in relation to public expenditure to all ministries / divisions and departments under them.

\section{Macro-economic Stability}

3.1 Propelled by higher growth in industrial and service sectors, the overall economic growth in FY 2006-07 is likely to be around 6.5 percent despite the political turmoil and hartals and poor weather for key rice crops. Export and remittance have been the bulwark of growth recording 19 percent and 27 percent respectively in the three quarters of this fiscal year. Credit to the private sector grew at an annualized rate of 19 percent during the same period. The domestic investment looked robust with 21 percent growth in LC settlement for capital machinery. 
3.2 Inflation, however, appears in the horizon as a major concern averaging 7 percent. The Bangladesh Bank is closely watching the situation and will exercise appropriate monetary policy option to contain inflation. The Authorities are aware that inflation hurts people, particularly the poor. It undermines economic stability and discourages investment; it deters growth and widens income inequality. To rein in inflation, the Government withdrew import duty on a number of items including rice and wheat. Bangladesh Bank has instructed commercial banks to encourage larger number of new importers of food to bring about greater competition. National Task Force and Task Forces in district and sub-district level regularly monitor the prices of essential commodities including a group devoted to the analysis of the prices. Government is to double its import of rice and wheat.

3.3 Cautious monetary policy has been matched by prudent fiscal policy. The overall fiscal deficit in FY 06 was kept below the target despite revenue shortfall. Our revenue to GDP ratio remains phenomenally low with 10.5 percent. The Annual Development Programme fell short in terms of implementation by about 20 percent due to resource inadequacy and implementation capacity constraints. For maintaining macro-economic stability, keeping public debt at a sustainable level and avoiding any crowding out impact on the private sector, the Government has limited domestic borrowing to 2 percent of the GDP in line with staff suggestions and prudential borrowing practice.

3.4 Of late, there has been growing interest from overseas investors for large scale foreign direct investment (FDI) in Bangladesh. The growth of FDI in Bangladesh averaged 16 percent from 2002 to 2007 . Very recently, the Mittal Group, the steel conglomerate, signed a Memorandum of Understanding with Board of Investment for investing US\$2.8 billion in coal, steel and power industries.

\section{Structural and Institutional Reforms:}

4.1 The commitment of the CTG to structural and institutional reforms has been demonstrated through several bold measures during the last 5 months. The reforms cover the financial sector, state-owned enterprises, the power and energy sector, telecommunications, fiscal policy and broad governance issues.

4.2 Three Nationalized Commercial Banks (NCBs) are about to be converted into public limited companies to enable them to operate like private banks. From January 2007, Authorities made it mandatory to have all commercial banks credit rated, and updated annually by a Credit Rating Company of good reputation to safeguard interest of the depositors and prospective investors. Reforms in insurance laws relating to protection of policy holders and supervision of insurance business are in process. To ensure international accounting, auditing and reporting standards, a Financial Reporting Act has been approved by the Council of Advisors. Money Laundering Prevention Act has been made more effective to prevent illegal transfer of funds.

4.3 In next fiscal year, more shares of SOEs and Government's share in commercial banks will be off-loaded in the Stock exchange. The listing of the new SOEs and the sale of bank shares is expected to bring about further vibrancy in the capital market which has grown significantly over the last three years. The Government is encouraging the private 
conglomerates and the mobile phone companies to raise capital from the market. The implementation of these steps will widen and deepen the capital market.

4.4 Despite the Government's flexibility in the divestment of Rupali Bank, the process has got stalled owing to frequent shifts in stance by the highest bidder. The Bangladesh Government has, time and again, acceded to the request of the bidder, and the present delaying tactics by the bidder has placed the Authorities in an embarrassing situation.

4.5 The revised FY 07 budget, the Government has allocated Taka 15 billion to make the quasi-fiscal costs of the Government more transparent. In FY 2007-08, the Government will assume the total liabilities of Bangladesh Petroleum Corporation (BPC), in the amount of Taka 75 billion arising out of administered fuel price over the past few years. BPC is being geared up to run on a commercial basis and will be allowed to adjust petroleum prices on a previously agreed automatic price adjustment formula.

4.6 One of the biggest challenges facing the CTG is tackling the power crisis, a legacy that will continue to affect the economy for at least 3 more years. We have made highest allocation increase of 51 percent in power sector and the Government is building quite a few more power plants. Private sector power producers are also encouraged. Power has been identified as a thrust sector and Bangladesh would appeal for larger soft-term loan for investment in this sector from development partners. In the other strategic transportation sector, reforms in the seaports of Chittagong and Mongla led to a reduction of ship turnaround time from 9 days to 4 days with handling costs cut down by 20 percent. Low revenue collection remains a fundamental problem in fiscal management for the Government. Revenue as a share of GDP continues to be stagnant coasting around 10.5 percent. The Authorities have identified this low revenue growth as the main challenge in the fiscal front. The Government has expressed their broad agreement with the April 2007 IMF Staff Report suggesting overhaul of tax legislation and separation of revenue collection from policymaking.

\section{PRGF Programme}

5.1 At the conclusion of this statement on behalf of my Authorities I wish to state that the PRGF engagement with the IMF during the past 4 years, along with budgetary support from the World Bank through DSCs, has been largely successful. A flexible exchange rate regime was introduced in 2003, discreetly timed and executed, without creating any turbulence in the market. GDP growth has been impressive sustained over the programme years, there has been sustained reduction of poverty and progress in several MDG targets. Several key structural reforms have been implemented. Price adjustments in fuel, gas and power have significantly reduced hidden quasi-fiscal costs of the Government. The corporatization of the NCBs, the issuance of unique taxpayer identification numbers to large tax payers, and the establishment of Large Taxpayers' Units, are examples of some significant reforms in the financial / fiscal sectors. However, the tax to GDP ratio remains stagnant. You will appreciate that this has been largely due to revenue loss owing to liberalization of international trade regime. The Programme target of an increment of 1.5 percent in revenue to GDP ratio during the period could not be met. 


\subsection{Post PRGF :}

Our Authorities concur with the broad gist of the Staff report and are prepared to go forward in: (a) initiating a detailed overview of the current tax legislation through a possible Technical Assistance package from the Fund. This would be with a view to streamlining existing legislation and plugging loopholes existing at present; (b) combining the two Large Tax Payers' Units (LTUs) and issuing Unique Tax Identification Numbers (UTINs) to all large taxpayers; (c) separating aspects of Tax policy and planning away from administration of tax collection. Our Authorities feel that these steps are indeed necessary for tax buoyancies to improve in the long run.

5.3 The CTG is committed to change. The CTG has in the last 5 months brought in more fundamental and institutional reforms than what was witnessed in the past several years. An Independent Election Commission for holding a free and fair election by end 2008, anti-corruption drive through Anti-Corruption Commission, banking and financial sector reforms are some of the major icons.

5.4. Many more important reforms will be forthcoming in the coming months. My Authorities' goal is to establish the conditions for sustainable and long-lasting reforms that are oriented to the welfare of the people, enhance efficiency and improve growth performance. The Government has weighed the three options provided in Staff Report for future engagement with the Fund and have resolved to pursue negotiation for a new PRGF. 